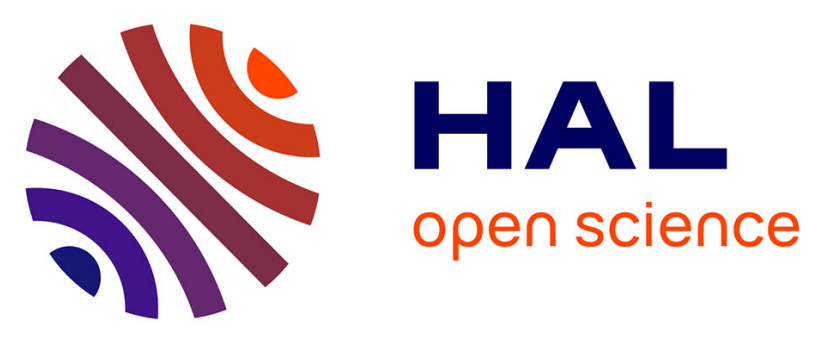

\title{
THE KRAMIS DEEP-SEA FAN OFF WESTERN ALGERIA: ROLE OF SEDIMENT WAVES IN TURBIDITIC LEVEE GROWTH
}

Nathalie Babonneau, Antonio Cattaneo, Bruno Savoye, Guy Barjavel, Jacques Déverchère, Karim Yelles

\section{To cite this version:}

Nathalie Babonneau, Antonio Cattaneo, Bruno Savoye, Guy Barjavel, Jacques Déverchère, et al.. THE KRAMIS DEEP-SEA FAN OFF WESTERN ALGERIA: ROLE OF SEDIMENT WAVES IN TURBIDITIC LEVEE GROWTH. Application of the Principles of Seismic Geomorphology to ContinentalSlope and Base-of-Slope Systems: Case Studies from Seafloor and Near-Seafloor Analogues, SEPM, pp.293-308, 2012, 978-1-56576-304-3. insu-00779477

\section{HAL Id: insu-00779477 https://hal-insu.archives-ouvertes.fr/insu-00779477}

Submitted on 22 Jan 2013

HAL is a multi-disciplinary open access archive for the deposit and dissemination of scientific research documents, whether they are published or not. The documents may come from teaching and research institutions in France or abroad, or from public or private research centers.
L'archive ouverte pluridisciplinaire HAL, est destinée au dépôt et à la diffusion de documents scientifiques de niveau recherche, publiés ou non, émanant des établissements d'enseignement et de recherche français ou étrangers, des laboratoires publics ou privés. 


\title{
Sponsored by
}

\author{
This publication by SEPM Society for Sedimentary Geology \\ Special Publication No. 99
}

Application of the Principles Seismic Geomorphology to Continental Slope and Base-of-slope Systems: Case Studies from Seafloor and Near-Seafloor Analogues

and all chapters are available open access (see license terms below) through a financial contribution from Shell.

Open Access Terms

\section{Creative Commons license: Attribution-NonCommercial-NoDerivs 3.0 Unported}

You are free:

- to Share - to copy, distribute and transmit the work

Under the following conditions:

- Attribution - You must attribute the work (but not in any way that suggests that they endorse you or your use of the work).

- Noncommercial - You may not use this work for commercial purposes.

- No Derivative Works - You may not alter, transform, or build upon this work.

With the understanding that:

- Waiver - Any of the above conditions can be waived if you get permission from the copyright holder.

- Public Domain - Where the work or any of its elements is in the public domain under applicable law, that status is in no way affected by the license.

- Other Rights - In no way are any of the following rights affected by the license:

$\circ$ Your fair dealing or fair use rights, or other applicable copyright exceptions and limitations;

- The author's moral rights;

- Rights other persons may have either in the work itself or in how the work is used, such as publicity or privacy rights.

- Notice - For any reuse or distribution, you must make clear to others the license terms of this work. Full License is available at $\underline{\mathrm{http}: / / \text { creativecommons.org/licenses/by-nc-nd/3.0/ }}$ 


\title{
THE KRAMIS DEEP-SEA FAN OFF WESTERN ALGERIA: ROLE OF SEDIMENT WAVES IN TURBIDITIC LEVEE GROWTH
}

\author{
NATHALIE BABONNEAU \\ Université de Brest, IUEM, UMR CNRS 6538 Domaines Océaniques, Place Nicolas Copernic, 29280 Plouzané, France \\ e-mail: Nathalie.Babonneau@univ-brest.fr \\ ANTONIO CATTANEO \\ IFREMER, Géosciences Marines, Laboratoire Environnements Sédimentaires, BP70, 29280 Plouzané, France \\ BRUNO SAVOYE (DECEASED) \\ GUY BARJAVEL \\ IFREMER, Géosciences Marines, Laboratoire Environnements Sédimentaires, BP70, 29280 Plouzané, France \\ JACQUES DÉVERCHÈRE \\ Université de Brest, IUEM, UMR CNRS 6538 Domaines Océaniques, Place Nicolas Copernic, 29280 Plouzané, France \\ AND \\ KARIM YELLES \\ CRAAG, BP 63, Route de l'Observatoire, Bouzareah, 16340 Alger, Algeria
}

\begin{abstract}
Aвsтract: The Kramis deep-sea fan extends over $45 \mathrm{~km}$ at the base of the western Algerian continental slope between 2000 and $2550 \mathrm{~m}$ water depth and covers an area of approximately $1200 \mathrm{~km}^{2}$. The Kramis Fan was initiated after Messinian time, evolved during the PlioQuaternary, and, is still active, as proved by submarine cable breaks during the 1954 Orléansville earthquake. The Kramis Fan is fed by two perpendicular canyons: the Kramis Canyon and the Khadra Canyon, merging in a single E-W-oriented channel confined at the foot of the slope. It is strongly asymmetric with a super-developed levee on the right-hand side of the channel, the Kramis Ridge.

Based on recent multibeam, side-scan sonar, and sediment core data (Maradja, 2003 and 2005, Prisma, 2004, and Prisme, 2007 cruises), we describe the morphology and internal structure of the fan and particularly the sediment ridge, showing marked lateral changes in the sediment-wave morphology and their association with a series of large scours in the intermediate part of the ridge aligned in the continuity of the Khadra Canyon direction. Overall, the Kramis Ridge is formed by turbidity currents overspilling the ridge crest, which is $100 \mathrm{~m}$ above the channel floor, with two exceptions. In the distal part of the ridge the subdued ridge-crest height probably causes continuous overspill, testified by sediment waves migrating parallel to the channel. The scours occur in the intermediate part of the ridge where the ridge height is only 50-60 m; scours are interpreted as the result of cyclic steps due to flow stripping of currents provided by the intersection of the Khadra Canyon with the Kramis Canyon and Channel system. The scours probably postdate the main growth of the Kramis Ridge and induce the local erosion of the ridge, which could correspond to a new channel initiation cutting the ridge. The superposition or the interaction of flows with different directions is responsible of the amplification of the size of the sediment waves with erosional downside flanks and their transformation in scours. The Kramis Fan provides a clear example of flow interaction to explain the presence of large sediment waves and scours on modern submarine fans.
\end{abstract}

KeY wORDs: Algerian margin, turbidity currents, sediment waves, scours

\section{INTRODUCTION}

Sediment waves are relatively common in deep-sea environments and reflect specific flow types and characteristics (Wynn and Stow, 2002). The sediment waves commonly observed in most modern turbidite systems concerns fine-grained turbidite deposits and are restricted to the overbank depositional elements or levees (Migeon et al., 2004; Migeon et al., 2000; Nakajima and Satoh, 2001; Normark et al., 1980; Normark et al., 2002; Wynn et al., 2000). They are generally well expressed where the turbidity currents preferentially overflow, for example in the external levee of a channel meander (Migeon et al., 2004) or at the surface of large sedimentary ridge (Migeon et al., 2006). In some cases, high-energy overflows induce local erosional processes in levees, forming series of scours (Fildani et al., 2006). One of the key questions is to understand the processes that form the scours, their relation to sediment waves, and their contribution to the evolution (growth and erosion) of levee deposits.

We recently discovered a deep-sea fan offshore western Algeria, where sediment waves and scours have a spectacular seafloor expression in a specific sector of the fan. The Kramis turbidite system includes one of the major deep-sea fans of the Algerian margin. In contrast to sediment waves and scours described in other turbidite environments (Fildani et al., 2006; Wynn and Stow, 2002), the field of high-amplitude sediment waves of the Kramis Fan is not located in the external levee of a channel meander, but results from the interaction of turbidity flows of two perpendicular canyons. The Kramis sedimentary system offers an opportunity to study the interaction between sediment waves and scours, and their role in the evolution of a large sedimentary ridge, and to better understand the overflow processes and their origin. 
In this paper, we use available bathymetry, side-scan sonar, and core data to present an overview of the sedimentary architecture of the Kramis deep-sea fan, including: (1) the description of the morphology and internal structure of one of the major fans of the Algerian margin, which has recorded very recent activity during the last earthquakes; (2) the identification of recent depositional processes and flow types that shaped the fan, based on cores and side-scan sonar images; (3) the interpretation of a possible structural control on the shape of the fan; and (4) the determination of the role of sediment waves in growth of turbidite levees.

\section{BACKGROUND}

The Algerian margin is a Cenozoic passive margin, presently reactivated in compression along the plate boundary between Africa and Europe (Fig. 1A). The Algerian coast has been affected by several large to moderate earthquakes that occurred in different structural segments (Yelles-Chaouche et al., 2006; Yelles et al., 2009). The margin deformation occurs both onshore in the coastal area and offshore along blind reverse faults that deform the seafloor (Déverchère et al., 2005; Domzig et al., 2006; Strzerzynski et al., 2010).

Until a few years ago, with some exceptions (Leclaire, 1972; Mauffret, 2007; Mauffret et al., 1998), the western Algerian margin was largely unknown offshore in spite of tectonic activity expressed by relatively frequent earthquakes and evidence for the occurrence of sediment gravity flows in the deep-sea environment in direct relation to earthquake events (El-Robrini et al., 1985; Heezen and Ewing, 1954). Along the western part of the Algerian margin (Oran-Ténès area), recent major earthquakes include the 1954 Orléansville earthquake and the $1980 \mathrm{El}$ Asnam earthquake (Meghraoui et al., 1986). The 1954 earthquake generated a turbidity current recorded by the rupture of several submarine cables downdip of the Kramis Fan study area (El-Robrini et al., 1985; Heezen and Ewing, 1954). El Robrini et al. (1985) proposed that the 1954 turbidity current originated in Khadra Canyon and affected the seafloor along a zone $150 \mathrm{~km}$ wide offshore of El Marsa City to the deep abyssal plain more than $120 \mathrm{~km}$ from the Algerian coast. This catastrophic event, recorded in the deep-sea environment, proves that turbidite systems are presently active along the western Algerian margin and that their activity can be directly linked to seismic activity of the margin.

Since 2003, a series of oceanographic cruises (Maradja 2003, Prisma 2004, Maradja 2 2005, Prisme 2007) have revealed the morphology of the Algerian margin and enabled the mapping of the superficial sedimentary structures (Déverchère et al., 2005; Domzig et al., 2009). The continental slope offshore Algeria is relatively narrow (5-6 km or less) and the continental slope is steep $\left(7-10^{\circ}\right.$; Fig. 1). Irregular seafloor escarpments in the continental slope are possibly associated with tectonic structures such as inverse faults and folds (Déverchère et al., 2005; Domzig et al., 2006). The slope is incised by numerous canyons, characterized by various size and morphology. The major canyons incising the Algerian continental slope feed deep-sea fans located at the base of the slope (Fig. 1A). Eight main deep-sea fans have been identified along the Algerian Margin, building large sediment accumulations between 2400 to $2700 \mathrm{~m}$ water depth; along the western Algerian margin, the Kramis Fan and the El Marsa Fan are the largest deep-sea fans built during PlioQuaternary Time (Domzig et al., 2009).

Submarine landslides are common and occur in a variety of settings: along the continental slope, along seafloor escarpments that are the seafloor expression of active tectonic struc- tures, and on the flanks of salt diapirs in the abyssal plain (Cattaneo et al., 2010). Gravity-flow deposits are common at the foot of the slope (Cattaneo et al., 2010; Dan et al., 2008; Domzig et al., 2009; Domzig et al., 2006).

The Algerian margin is characterized by a Mediterranean climate, with a relatively dry summer season and a wet season during winter, with frequent and sudden floods by ephemeral rivers called oueds (Boudjadja et al., 2003). No large river exists in the western part of the margin: the Kramis Oued is short, and its source is located in the coastal mountains. The most important Algerian river is the Cheliff River, located to the west of the study area, with a mean annual streamflow of $17.4 \mathrm{~m}^{3} \mathrm{~s}^{-1}$ (BfG, 1999) and a mean annual discharge of suspended sediment of $15.4 \times 10^{6} \mathrm{t}$ (Probst and Amiotte Suchet, 1992), but no large canyons and deep-sea fan are visible off the Cheliff River mouth. Recent tectonic activity has been responsible for the formation of coastal relief and probably induced important changes in the hydraulic network (watershed organization), as has been demonstrated in the area of Algiers (Boudiaf, 1996).

The oceanic circulation in the western Mediterranean Sea is characterized by a general anticlockwise flow along the continental slope, particularly well expressed in the south (Millot, 1999). Along the Algerian margin, the oceanographic circulation is dominated by the "Algerian current" from the Gibraltar Strait to the Tunisian coast (Millot, 1999). At mesoscale, an important variability of the circulation of the water masses is observed, and particularly a series of coastal eddies $(50-100 \mathrm{~km}$ in diameter) in the Algerian basin directly influenced by seasons.

\section{DATA AND METHODS}

The results presented in this paper are based on analysis of data acquired during Maradja 1 and 2 cruises (2003 and 2005), and complementary data collected during Prisma (2004) and Prisme (2007) cruises. Available data include mini-GI guns multichannel seismic profiles, $3.5 \mathrm{kHz}$ seismic profiles, multibeam EM300 bathymetric and backscatter data, deep-tow SAR side-scan sonar data, and sediment gravity cores. The bathymetric and backscatter data were acquired with a Simrad EM300 dual multibeam sounder (Figs. 1, 2). The processing of EM300 data provided a final grid with 50 m horizontal spacing and an average vertical resolution around $\pm 2 \mathrm{~m}$.

Seismic-reflection lines were acquired during the Maradja 2003 cruise (Figs. 1B, 3). Lines Mdjs81 and Mdjs83 are highresolution seismic profiles collected at 5 knots, using a seismic source of six small mini GI air guns shooting at a rate of $10 \mathrm{~s}$ (mean frequency $120 \mathrm{~Hz}$ ) and a 96-channel streamer $2500 \mathrm{~m}$ long. The vertical resolution of the profiles is about 10 meters. Chirp echo-sounder profiles were acquired during the Maradja 1 and 2 cruises. The quality of the Chirp sections (signal resolution and penetration) attains at places a vertical resolution of 1 meter with a maximum signal penetration of about $100-150 \mathrm{~ms}$. The Chirp data were used to obtain a relatively good metric correlation with sediment cores.

High-resolution side-scan sonar images and $3.5 \mathrm{kHz}$ echosounder profiles were obtained with the SAR system during Maradja 2 cruise in 2005. TheSAR system, developed by Ifremer, is towed at about $100 \mathrm{~m}$ above the seafloor at 2 knots and is equipped with a very high-resolution side-scan sonar (170-190 $\mathrm{kHz}$ ) and a $3.5 \mathrm{kHz}$ echo-sounder profiler. The SAR backscatter images provide information on seafloor texture and microtopography.

Sediment cores collected in the Kramis Fan include six piston cores acquired during four distinct campaigns (KMDJ07, 

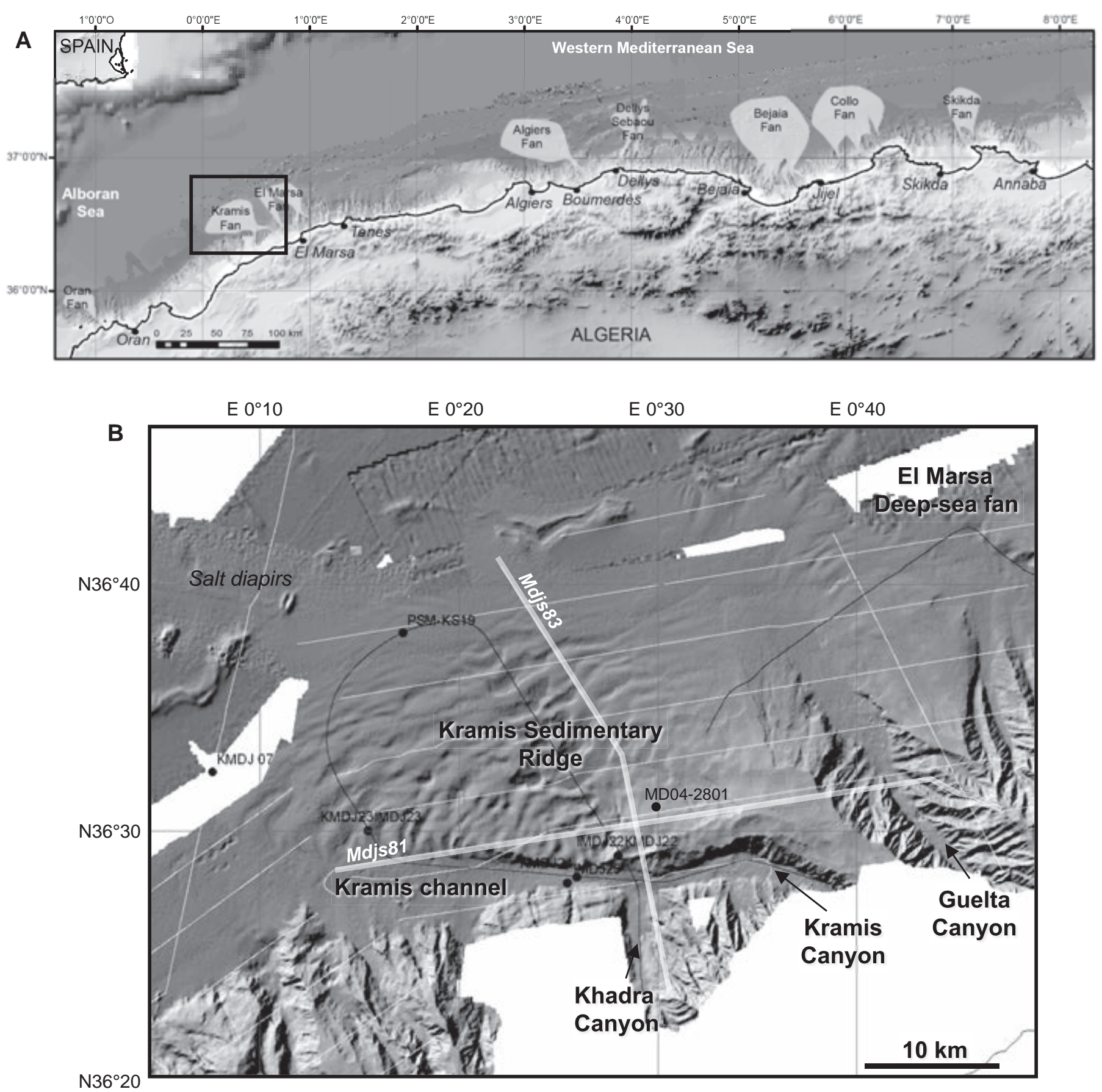

FIG. 1.-A) General location map of the Algerian margin, showing the main sedimentary deep-sea fans, B) bathymetric map and location of Maradja and Prisme data in the Kramis fan Area (bathymetry, multichannel seismic lines, Chirp echo-sounder profiles, SAR deep-towed side-scan sonar, and piston cores).

MD04-2801, KMDJ22, KMDJ23, KMDJ24, and PSM-KS19), and one interface core (IMDJ25). Basic information of the cores is in Table 1 (location in Figure 1B). In this paper, we focus especially on the three piston cores located in the Kramis Ridge: Core KMDJ22, sampling the upper-ridge crest; core KMDJ23, sampling the lower-ridge crest; and core PSM-KS19, sampling the distal part of Kramis Fan.

\section{RESULTS}

Morphology of the Kramis and El Marsa Turbidite Systems

The Kramis and El Marsa turbidite systems are located on the western Algerian margin, offshore the town of El Marsa (Fig. 1). Two deep-sea fans are visible in bathymetric data and were 


\section{A Shaded bathymetric map}

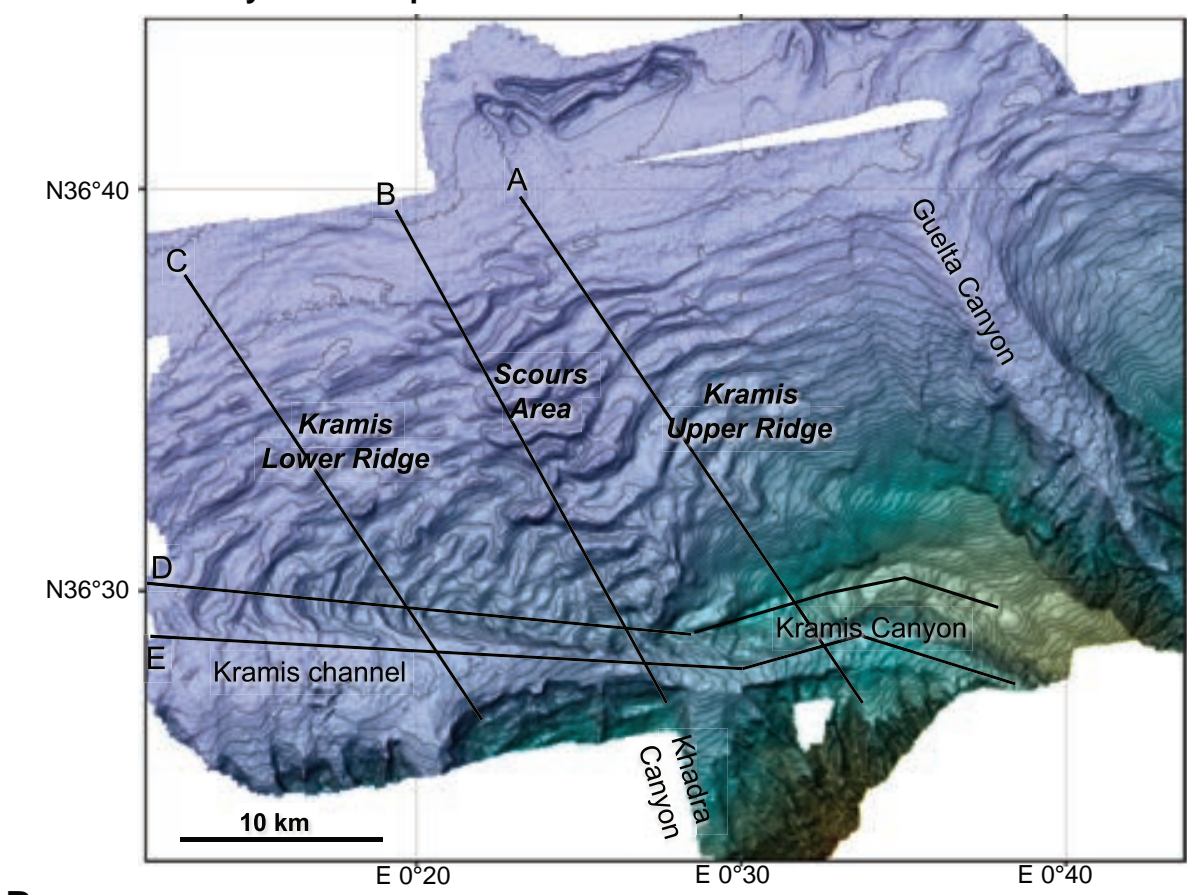

B Bathymetric profiles (depth in meters)
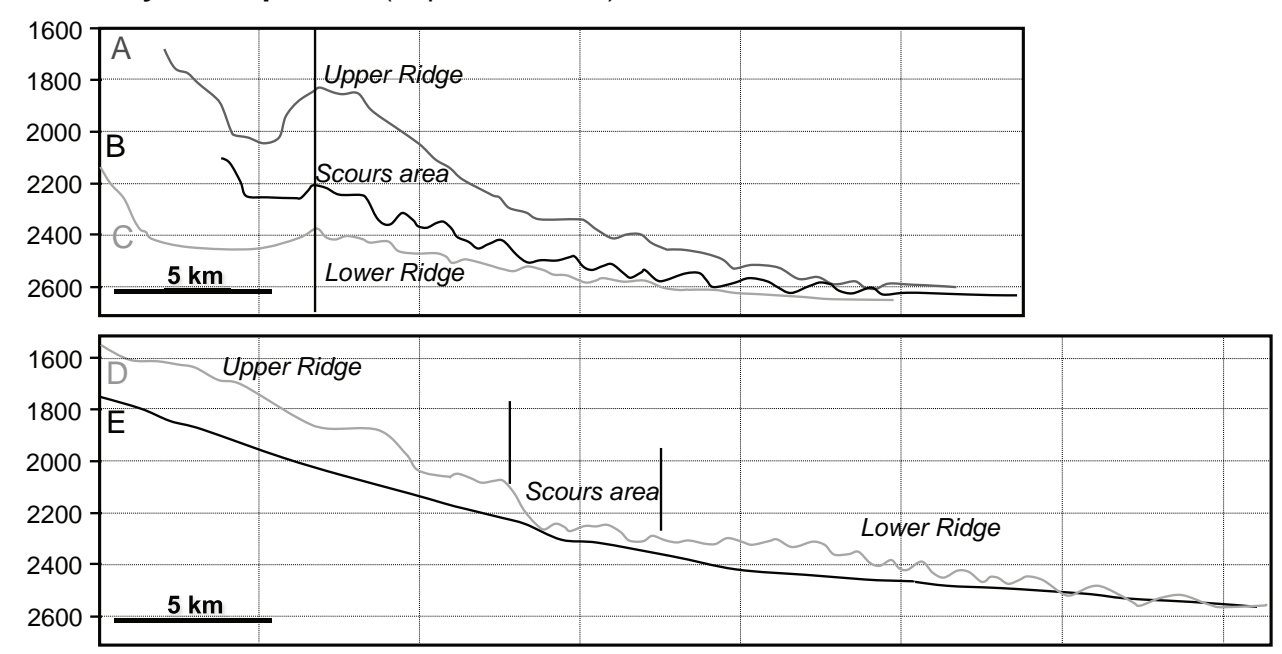

FIG. 2.-A) Shaded and contoured bathymetric map (Contour interval $20 \mathrm{~m}$ ), focused on the Kramis sediment ridge. B) Bathymetric profiles across and along the sediment ridge.

initially described together as the "El Marsa Fan" by Mauffret et al. (1998). In fact, based on the new bathymetric data, they consist of two distinct deep-sea fans: the Kramis Fan and the El Marsa Fan (Fig. 1).

The El Marsa turbidite system, located in the eastern area, is fed by the Guelta and the El Marsa canyons (location in Fig. 1). The two canyons converge and form a coalescent tubidite accumulation at the base of the slope. The Guelta Canyon (visible in Figs. 1 and 2) is straight and narrow in the upper part and becomes wider in the lower part. Sediment waves are visible laterally to the lower part of the canyon.

The Kramis turbidite system is located in the western part, at the base of the continental slope in water depths between 2000 and $2650 \mathrm{~m}$ (Fig. 1B). It is about $50 \mathrm{~km}$ long and wide. It is fed by the Khadra and the Kramis canyons. These two canyons are rectilinear and have perpendicular orientations: the Khadra Canyon is N-S oriented, and the Kramis Canyon is E-W oriented (Fig. 2). Downslope of the intersection between the two canyons, the Kramis Canyon changes into the straight E-W-oriented channel, named Kramis Channel, running parallel to the base of the slope. The longitudinal depth profile of the Kramis Canyon and Channel is relatively regular and smooth (profile E in Figure 2), while the Khadra Canyon depth profile is steeper. At the intersection of the two canyons, a slope break is visible between the Khadra Canyon profile and the Kramis Channel profile (profile E in Figure 2). On the right side of the Kramis Canyon and Channel 

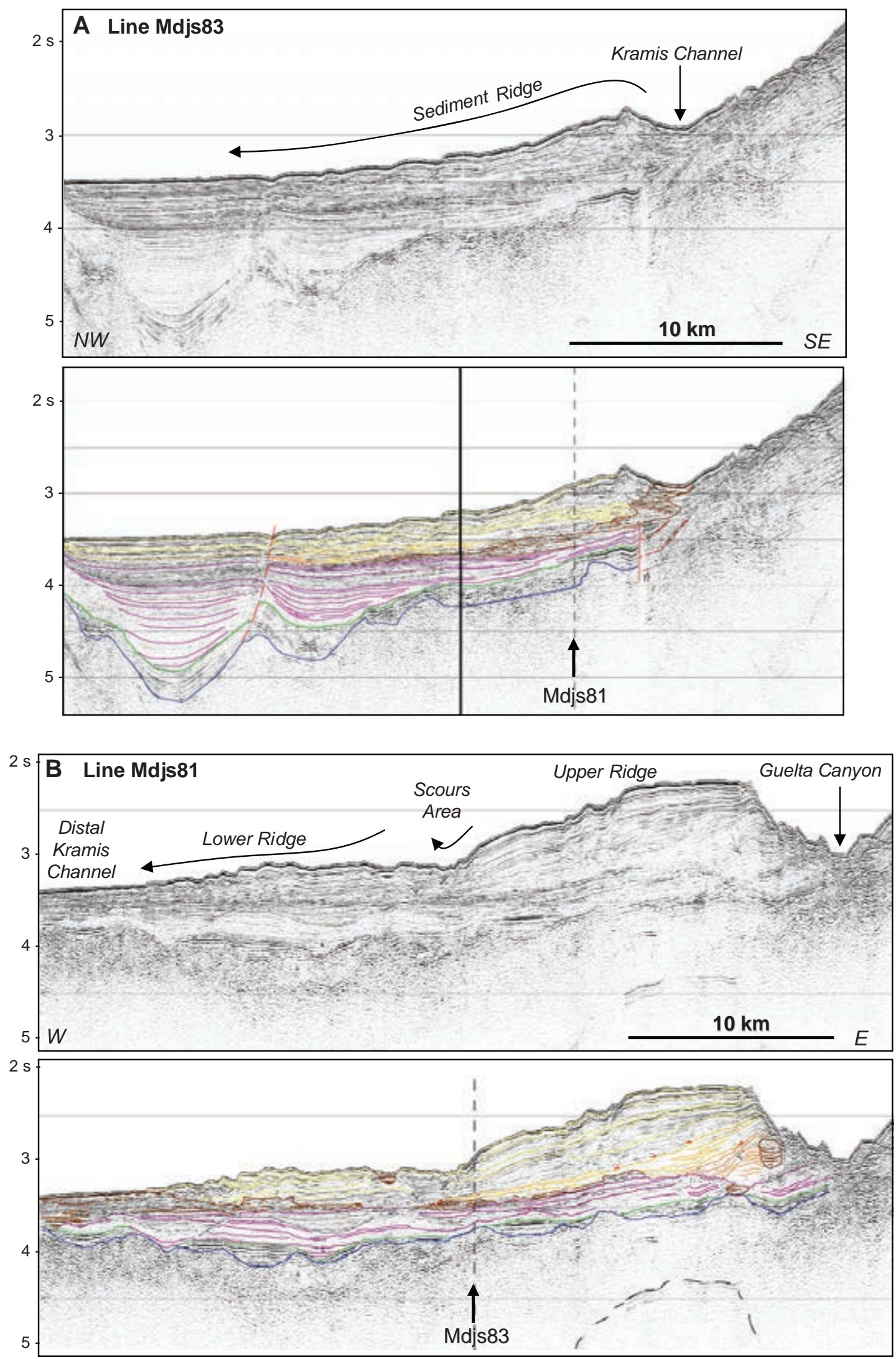

FIG. 3.-Seismic lines across the Kramis sediment ridge (see location in Figure 1): A) Seismic line Mdjs83, across the Kramis channel and ridge, and $\mathbf{B})$ seismic line Mdjs81, along the margin. 
TABLE 1.-Basic information about sediment cores.

\begin{tabular}{|l|c|c|c|c|l|}
\hline Core & $\begin{array}{c}\text { Lat N } \\
\text { DD MM,xx }\end{array}$ & $\begin{array}{c}\text { Lon E } \\
\text { DD MM,xx }\end{array}$ & $\begin{array}{c}\text { Water depth } \\
(\mathbf{m})\end{array}$ & $\begin{array}{c}\text { Length } \\
(\mathbf{c m})\end{array}$ & Location \\
\hline KMDJ07 & $36^{\circ} 32.42^{\prime}$ & $00^{\circ} 07.59^{\prime}$ & 2630 & 636 & Distal fan \\
\hline MD04-2801 & $36^{\circ} 30.99^{\prime}$ & $00^{\circ} 30.03^{\prime}$ & 2067 & 2482 & eastern-ridge crest \\
\hline KMDJ22 & $36^{\circ} 29.00^{\prime}$ & $00^{\circ} 28.01^{\prime}$ & 2051 & 671 & eastern-ridge crest \\
\hline KMDJ23 & $36^{\circ} 30.00^{\prime}$ & $00^{\circ} 15.42^{\prime}$ & 2450 & 756 & western-ridge crest \\
\hline KMDJ24 & $36^{\circ} 28.12^{\prime}$ & $00^{\circ} 25.41^{\prime}$ & 2314 & 136 & channel floor \\
\hline IMDJ25 & $36^{\circ} 27.89^{\prime}$ & $00^{\circ} 25.44^{\prime}$ & 2300 & 12 & channel floor \\
\hline PSM KS19 & $36^{\circ} 38.04$ & $00^{\circ} 17.18^{\prime}$ & 2626 & 865 & Distal fan \\
\hline
\end{tabular}

system, a large asymmetrical ridge, the Kramis Ridge, corresponds to a unique and super-developed levee of the Kramis Channel.

The present expression of the Kramis Fan in the seafloor morphology consists of the Kramis Channel, the Kramis Ridge, and the distal basin. The Kramis Fan lies at the foot of the slope with an overall asymmetric shape. The distal extremity of the Kramis Fan does not show morphological expression. Topographichighs associated with salt diapirs and walls possibly limit the longitudinal propagation of turbidity currents in the distal part of the ridge.

The morphology of the ridge crest bordering the right side of the Kramis Channel is irregular, as shown by the profile D (Fig. 2). Along the canyon, the ridge is more than $100 \mathrm{~m}$ high above the canyon floor. At the intersection of the Kramis Canyon with the Khadra Canyon, the ridge height abruptly decreases. Downdip of the intersection area, the ridge height progressively increases to $100 \mathrm{~m}$ and then decreases to minimal heights in the distal area. Along the Kramis Channel, the morphology of the ridge shows large undulations: up to $50 \mathrm{~m}$ in amplitude and $1 \mathrm{~km}$ in wavelength (profile D in Figure 2). These undulations are interpreted as sediment waves formed by turbidity-current overflows by analogy to many other examples described in the literature worldwide (Migeon et al., 2000; Normark et al., 2002; Wynn and Stow, 2002).

\section{Seismic Architecture of the Kramis Fan}

Seismic profiles Mdjs83 and Mdjs81b cross the Kramis Fan (location in Figure 1B), with limited penetration below a horizon (blue reflector in Figure 3) which is interpreted as the Messinian erosional surface (MES) based on identification of similar reflectors in regional studies (Lofi et al., 2005). The Mdjs83 profile cuts the fan along a north-south axis, crossing the main channel and the Kramis Ridge (Fig. 3A). The Mdjs81b profile is a longitudinal section of the ridge: it cuts the fan along an east-west axis following the base of the slope (Fig. 3B); on its eastern side, it crosses the Guelta canyon, which feeds the El Marsa turbidite system.

The overall architecture of the Kramis and El Marsa turbidite systems is built upon a major erosional surface of regional extent in the Mediterranean: the Messinian erosional surface (MES) and its distal equivalent. The MES is well marked in seismic profiles and shows a very irregular geometry. Based on regional studies (Dos Reis et al., 2005; Lofi et al., 2005), the MES is correlated distally with a deformed transparent unit corresponding to salt diapirs and gravity deformation of Messinian salt deposits that cover the deep western Mediterranean. Above the MES horizon, four seismic units are identified in the study area.

Unit 1, at the base and immediately above the MES, is characterized by continuous high-amplitude and low-frequency reflec- tors (between blue and green reflectors in Figure 3). By analogy with other seismic data collected across the Mediterranean Sea, particularly the acoustic properties and the comparable depth in the stratigraphic succession, Unit 1 is interpreted as the upper Messinian evaporites (Lofi et al., 2005; Mauffret et al., 1998). Unit 1 is relatively irregular in thickness and is better developed in the deepest part of the basin between the salt diapirs and along topographic lows of the Messinian erosional surface.

Unit 2 is defined by low-amplitude and low-frequency subparallel reflectors (pink reflectors in Fig. 3) onlapping onto topographic highs. Reflectors are parallel and continuous, apart from onlap geometries. They probably correspond to the emplacement of marine mud with alternating hemipelagic and turbidite (or contourite) deposits. Unit 2 overlaps Unit 1 with variable thickness, and it shows the maximum thickness towards the basin. In profile Mdjs81b, the top of Unit 2 is locally truncated in the eastern part of the profile (Fig. 3). The origin of this erosion is probably due to initial incision of the Guelta Canyon.

Unit 3 consists of discontinuous high-amplitude reflections and chaotic packets with limited lateral extent (brown reflectors in Figure 3). This unit is interpreted as channel deposits. Unit 3 (brown) is typical of channel-floor deposits and shows the progressive and irregular channel migration upslope, during the Plio-Quaternary.

Unit 4 is composed of medium-amplitude, high-frequency, continuous reflectors (yellow reflectors in Figure 3). The reflectors are not clearly continuous and present large undulations. This unit corresponds to the levee deposits forming the Kramis Ridge, and the wavy reflectors are interpreted as sediment waves.

Units 3 and 4 are the youngest units and are related to two different turbidite sub-environment elements and are synchronous. Unit 4 corresponds to levee accumulations migrating upslope simultaneously with the channel migration (Unit 3). Units 3 and 4 are well developed from the Guelta Canyon to the western part of the Kramis Fan. The oldest turbidite deposits visible in seismic lines are focused below the Guelta canyon. The channel facies (Unit 3) is (a) discontinuous below the upper ridge, indicating possible initial migration of the channel by avulsions, and (b) continuous below the lower ridge, indicating the progressive lateral migration of the Kramis channel to its present location.

Based on the descriptions presented above and the relative chronology of seismic units, it is possible to infer that the Kramis Fan was initiated during the Pliocene (after Unit 2). By correlating the different seismic units, and particularly channel facies, we identified three main stages of evolution of the deep-sea fan (Fig. 4). Stage 1, after the Messinian, is characterized by the 
presence of a small N-S-oriented channel with wide and well preserved levees on both sides. Stage 2 is marked by an abrupt avulsion of the channel to a SE-NW direction. After the avulsion, the channel started to gradually migrate to southwest (toward the foot of the slope). Stage 3 represents the present condition, with the development of the ridge by levee aggradation (Fig. 4).

\section{The Sediment-Wave Fields over the Kramis Ridge}

Seafloor undulations, interpreted as sediment waves, are visible on a shaded relief map (Fig. 2). They are present everywhere over the Kramis Ridge in a water-depth range of 2200 to $2600 \mathrm{~m}$. The morphology of these sediment waves is not homogeneous: sediment waves have variable orientation, shape, amplitude, wavelength, and symmetry. It is possible to distinguish four areas, showing different morphological characters, based on the bathymetric map and profiles A, B, C, and D (Fig. 2): (1) the eastern ridge area on the right side of the Kramis Canyon, upslope of the convergence point with the Khadra Canyon; (2) the "scours area", a narrow area (5 $\mathrm{km}$ wide) located just in front of the Khadra Canyon; (3) the western ridge area on the right side of the Kramis Channel, downstream of the convergence point with the Khadra Canyon; and (4) the Kramis Channel levee crest, corresponding to the crest of the lower Kramis Ridge, located along the channel and showing changes of the wave-crest morphology in plan view. In Table 2, the main morphological characteristics of the four distinct areas of sediment waves are presented, with values for the wavelength, the wave amplitude (or height), the regional slope, and a characterization of the symmetry and the longitudinal evolution of wavelength and amplitude, and of the crest direction and form. The values can be compared with the data synthesized by Wynn and Stow (2002).

In the eastern ridge area (profile A across the upper ridge in Figure 2), the Kramis Canyon is $2 \mathrm{~km}$ wide and has a steep lateral margin, and the ridge crest is more than $200 \mathrm{~m}$ high above the channel floor. The sediment waves are crescent shaped and have a maximum amplitude of $25-20 \mathrm{~m}$, with height decreasing basinwards, and a wavelength of about $1.5-2 \mathrm{~km}$. The upper ridge crest shows small scarps that may have resulted from local slope instabilities.

Along the scours area (profile B in Fig. 2), the channel is $3 \mathrm{~km}$ wide and the Kramis Ridge crest is lower than $50 \mathrm{~m}$ above the channel floor. The sediment waves have an average amplitude of $50-60 \mathrm{~m}$ (as high as the channel depth), with wavelength increasing from $0.9 \mathrm{~km}$ to $1.9 \mathrm{~km}$ downslope. They form 5-km-long convex-up crescent morphologies similar to the scours described on the levee of the Monterey East channel (Fildani et al., 2006). Both in the scours area of the Kramis Ridge and in the Monterey area, the sediment waves show the most asymmetrical shape and have the maximum wave amplitude, with the steepest sides toward the basin.

In the western ridge area (profile $\mathrm{C}$ in Figure 2), the Kramis Channel is as wide as $5 \mathrm{~km}$ on the profile C (Fig. 2) and the levee height decreases (from $60 \mathrm{~m}$ to $10 \mathrm{~m}$ ) down to the distal part of the Kramis channel. The sediment waves have a semicircular shape. The profiles of the sediment waves (Profile C) is smoother and their wavelength is more regular (around $1.5 \mathrm{~km}$ ), with amplitude between 50 and $20 \mathrm{~m}$ decreasing downslope.

Along the Kramis Channel levee crest (profile D in Figure 2), the amplitude of the waves is steady, and their wavelength is shorter (about $1 \mathrm{~km}$. The sediment waves form a succession of concaveup crescents with inter-wave zones that are particularly deep (Fig. 2).

Chirp echo-sounder profiles Mdjsar32 and 34 show the internal structure of the sediment waves over the Kramis Ridge (Fig. 5). Profile Mdjsar32 is a section of the sediment waves of the lower ridge (Fig. 5A). In this profile, the sediment waves have variable amplitude $(<50 \mathrm{~m})$ and wavelength $(1.0$ to $1.5 \mathrm{~km})$. They are asymmetrical with steeper down-side flanks, similar to sediment waves described in other deep-sea fans (Normark et al., 2002; Wynn and Stow, 2002). There is an important aggradation of the updip flank of the sediment waves. Correlation of reflectors from the updip to the downdip flanks of the sediment waves is difficult, except in the uppermost layers. The youngest continuous layers in seismic sections are more than three times thicker on the updip flank than on the downdip flank.

Profile Mdjsar 34 (Fig. 5B) is a section of the scours area and shows sediment waves that are asymmetrical and with an upslope-dipping flank. The downdip flank of the sediment waves is very steep. The areas located between sediment waves are intensely incised and confirm the action of erosional processes. A detail of the superficial morphology of the scours is visible in Figure 6, with a high-resolution side-scan sonar image (SAR) and a $3.5 \mathrm{kHz}$ echo-sounder profile. In the SAR image, the downdip flanks of the sediment waves are characterized by erosional

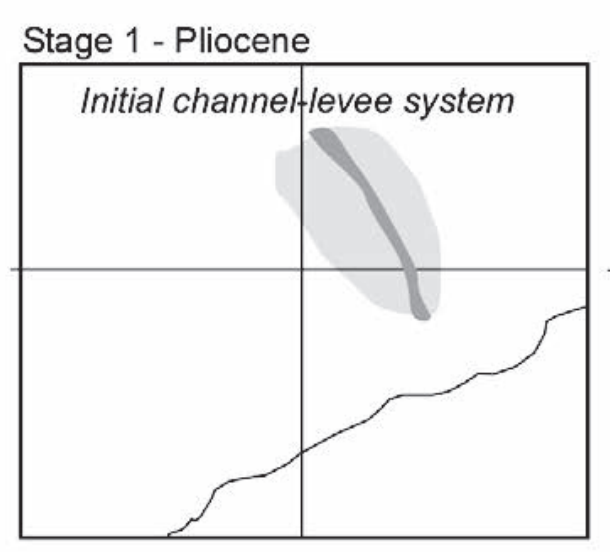

Stage 2 - Quaternary evolution

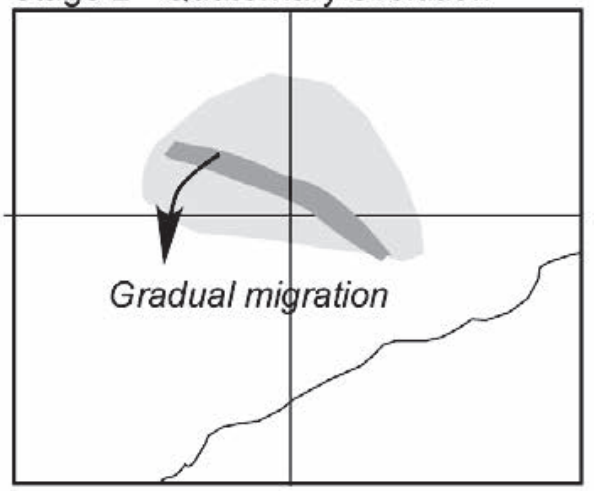

Stage 3 - Present

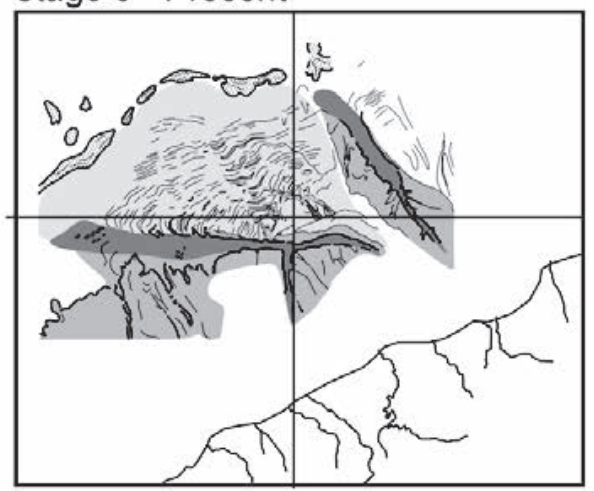

FIG. 4.-Series of sketches showing proposed evolution of the Kramis Fan, based on the interpretation of seismic lines. Stage 1 is the initial location of a symmetrical channel-levee system at the lower Pliocene, stage 2 represents the lateral migration of the channel during the Quaternary, and stage 3 is the present morphology of the Kramis Fan (channel in dark gray and levee deposits in light gray). 
TABLE 2.-Morphometric parameters of the sediment waves. Information reported in this table in the last column (after Wynn and Stow, 2002) corresponds to waves formed by turbidity-current processes in levee environment (fined-grained sediment dominated by mud and silt).

\begin{tabular}{|l|l|l|l|l|l|}
\hline & $\begin{array}{l}\text { (1) The Kramis } \\
\text { eastern-ridge } \\
\text { field }\end{array}$ & $\begin{array}{l}\mathbf{( 2 )} \text { The Kramis } \\
\text { scours area }\end{array}$ & $\begin{array}{l}\text { (3) The Kramis } \\
\text { western-ridge } \\
\text { field }\end{array}$ & $\begin{array}{l}\text { (4) The Kramis } \\
\text { channel ridge } \\
\text { crest field }\end{array}$ & $\begin{array}{l}\text { Wynn and Stow } \\
\text { (2002) } \\
\text { Classification }\end{array}$ \\
\hline Wavelength & $1.5-2 \mathrm{~km}$ & $0.9-1.9 \mathrm{~km}$ & $1,5 \mathrm{~km}$ & $0.9-1.1 \mathrm{~km}$ & Up to $7 \mathrm{~km}$ \\
\hline Amplitude & $15-30 \mathrm{~m}$ & $50-60 \mathrm{~m}$ & $20-50 \mathrm{~m}$ & $30-50 \mathrm{~m}$ & Up to $80 \mathrm{~m}$ \\
\hline Slope & $2.3-0.8^{\circ}$ & $2.3-0.2^{\circ}$ & $1.1-0.5^{\circ}$ & $1-0.5^{\circ}$ & $0.7-0.1^{\circ}$ \\
\hline Asymmetry & $\begin{array}{l}\text { Variable: short } \\
\text { side upslope }\end{array}$ & $\begin{array}{l}\text { Steep and short } \\
\text { side downslope }\end{array}$ & $\begin{array}{l}\text { Variable: short } \\
\text { side upslope }\end{array}$ & $\begin{array}{l}\text { Mainly } \\
\text { symmetrical }\end{array}$ & $\begin{array}{l}\text { Decreases } \\
\text { downslope }\end{array}$ \\
\hline $\begin{array}{l}\text { Wavelength } \\
\text { evolution }\end{array}$ & $\begin{array}{l}\text { Increasing } \\
\text { downslope }\end{array}$ & $\begin{array}{l}\text { Increasing } \\
\text { downslope }\end{array}$ & $\begin{array}{l}\text { Increasing } \\
\text { downslope }\end{array}$ & $\begin{array}{l}\text { Increasing } \\
\text { downslope }\end{array}$ & $\begin{array}{l}\text { Increasing } \\
\text { downslope }\end{array}$ \\
\hline $\begin{array}{l}\text { Amplitude } \\
\text { evolution }\end{array}$ & $\begin{array}{l}\text { Decreasing } \\
\text { downslope }\end{array}$ & Quite constant & $\begin{array}{l}\text { Decreasing } \\
\text { downslope }\end{array}$ & Quite constant & $\begin{array}{l}\text { Decreasing } \\
\text { downslope }\end{array}$ \\
\hline $\begin{array}{l}\text { Crests } \\
\text { direction }\end{array}$ & $\begin{array}{l}\text { Perpendicular to } \\
\text { regional slope }\end{array}$ & $\begin{array}{l}\text { Convex } \\
\text { Crescent }\end{array}$ & $\begin{array}{l}\text { Perpendicular } \\
\text { to regional } \\
\text { slope }\end{array}$ & $\begin{array}{l}\text { Concave } \\
\text { Crescent }\end{array}$ & $\begin{array}{l}\text { Perpendicular to } \\
\text { regional slope }\end{array}$ \\
\hline
\end{tabular}

furrows parallel to the current directions (NNW). The $3.5 \mathrm{kHz}$ profile also shows truncations, proving the erosional character of these structures, which can be described as erosional sediment waves, because these waves are depositional features with erosional troughs.

\section{Sedimentary Facies of the Kramis Ridge}

CORES KMDJ24 and IMDJ25 were collected in the Kramis Channel floor (Fig. 1B). They are relatively short (KMDJ24 is 1.38 $\mathrm{m}$ long, IMDJ 25 is $0.12 \mathrm{~m}$ long), probably because of the difficulty of coring in coarse or compacted sediment. In both cores, the sediment collected is gray mud with indurated mud clasts. The presence of mud clasts could be the result of slope instabilities of the canyon or channel flanks.

MD04-2801 is a 25-m-long Calypso piston core located on the crest of the Kramis upper ridge. The upper 10 meters is composed of silty mud with local accumulations of plant debris and foraminifera. These silty muds are interpreted as hemipelagic deposits. Their presence suggests that turbidity currents have not fed this part of the upper ridge for thousands of years. Based on cable breaks associated with earthquakes, turbidity currents have been active in the Kramis canyon and channel, but probably with volumes too small to overflow this part of the ridge.
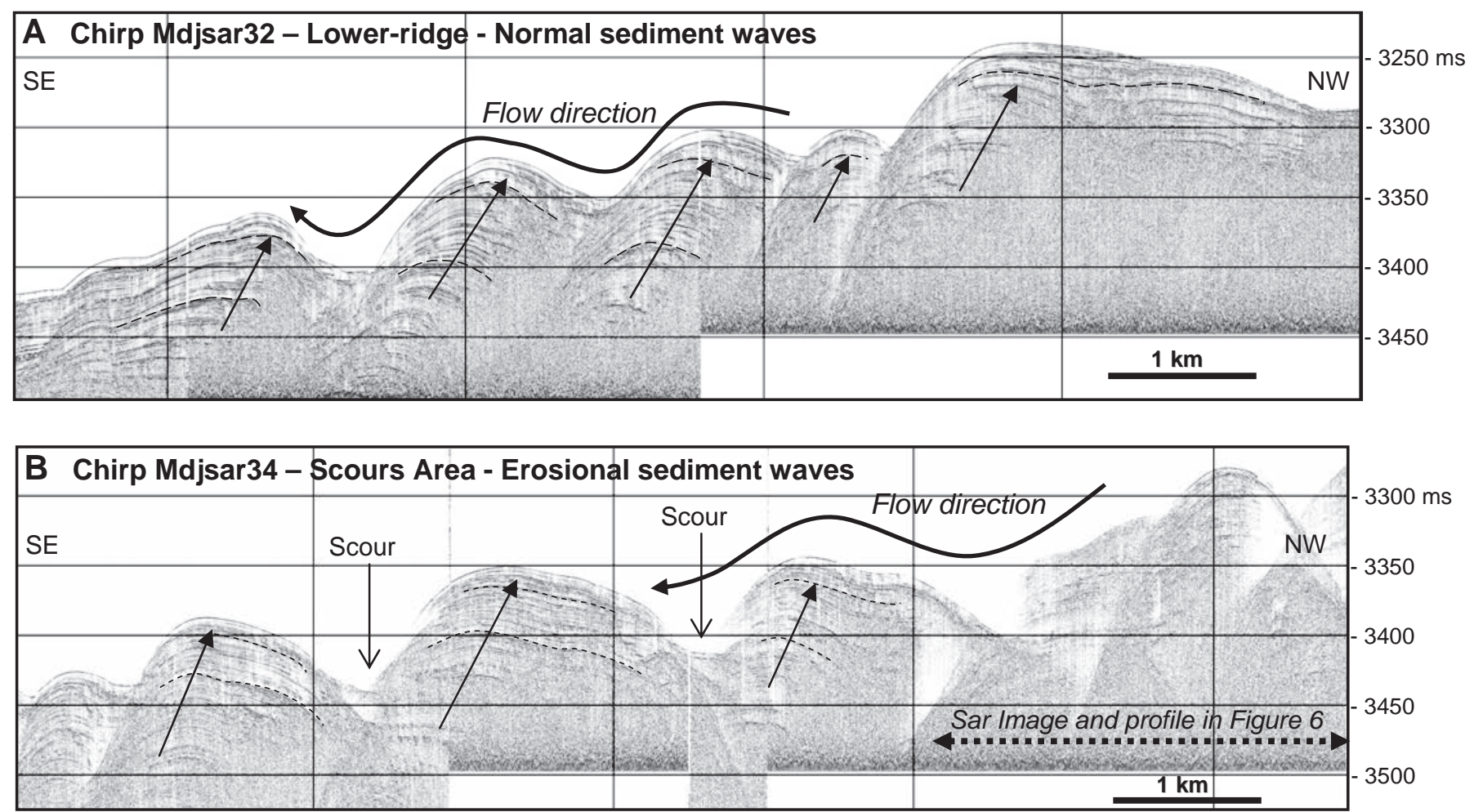

FIG. 5.-Chirp echo-sounder sections across the well-developed sediment waves of the Kramis sediment ridge (see location in Figure 4): A) Chirp section Mdjsar32, and B) Chirp section Mdjsar34. 


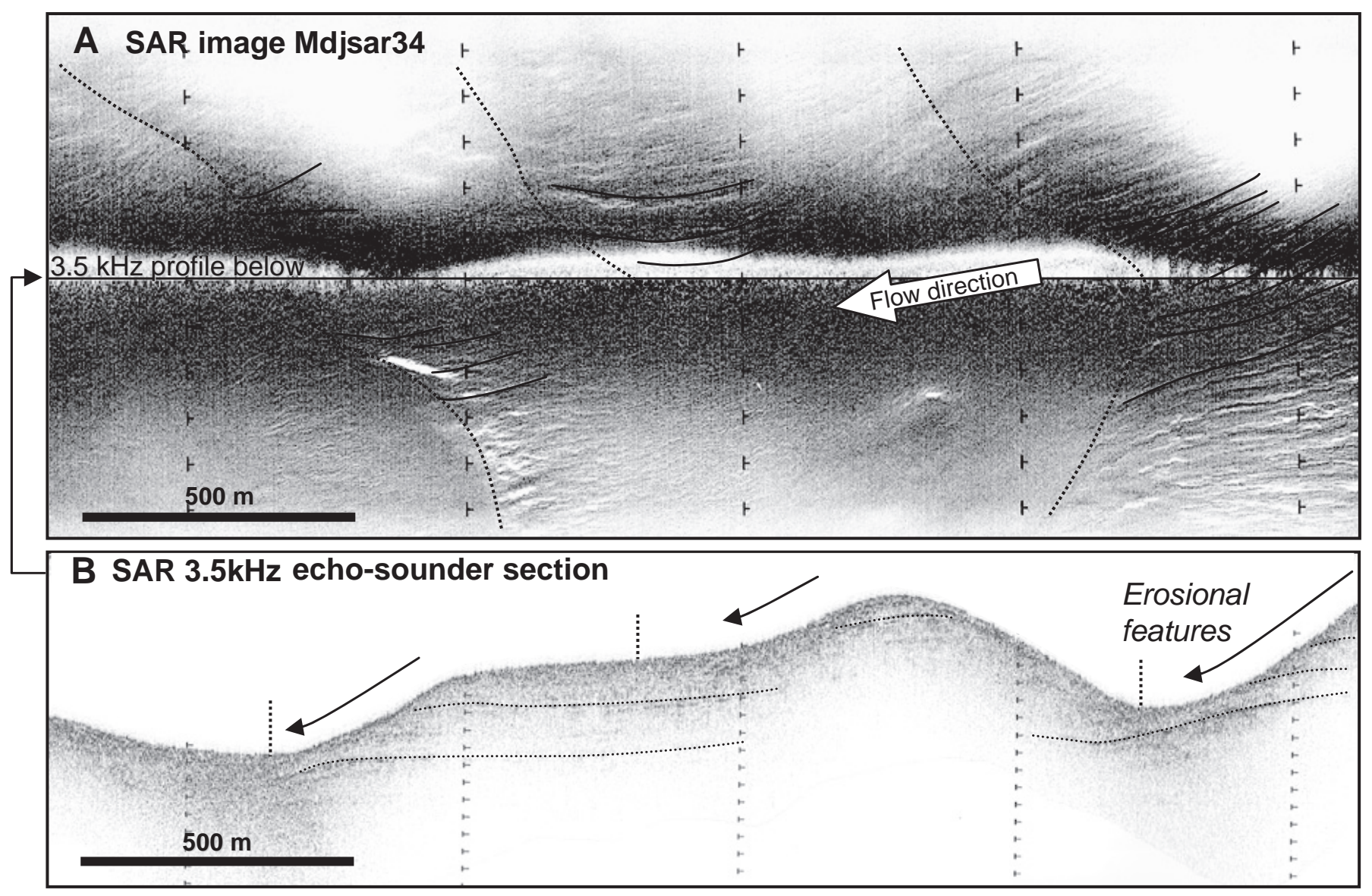

FIG. 6.-A) SAR image (deep-towed side-scan sonar) Mdjsar 34 across erosional sediment-wave structures (see location in Figure 5), and B) SAR echo-sounder section corresponding to the SAR image.

The lower part of core MD04-2801 (between $10 \mathrm{~m}$ and 25 mbsf-meters below seafloor) is composed of a succession of fine-grained turbidite deposits, composed of silty mud sequences. Each turbidite deposit consists of a thin basal silt layer $(<1 \mathrm{~cm})$, overlain by a silty mud interval. The bases of the silt layers are sharp, and the deposit is normally graded. Muddy intervals show abundant bioturbation, local faint laminations, fine organic debris, and rare foraminifera. These deposits are interpreted as a Tde Bouma sequence and correspond to fine-grained levee deposits formed by very dilute turbidity currents overflowing from the Kramis Canyon, alternating with hemipelagic sedimentation. In this area, the canyon relief is about $200 \mathrm{~m}$ high, and only the thickest turbidity currents could overflow.

Piston core KMDJ22 is $6.71 \mathrm{~m}$ long and is located on the ridge crest, immediately updip from the scours area (Fig. 1B). Core KMDJ22 is composed mainly of silty mud, with millimeterthick silt beds. These silt beds are interpreted as fine-grained turbidites likely formed by turbidity-current overflow. Contrary to MD04-2801, there is no thick hemipelagic accumulation at the top of the core. This suggests recent overflows of turbidity currents at this location of the ridge, probably due to a lower channel relief (about $120 \mathrm{~m}$ high). Near the base of the core, at about 5.8 mbsf, a 3-cm-thick bed of fine sand is present (Fig. 7), indicating a higher-energy current able to transport sand $120 \mathrm{~m}$ above the channel floor.
Piston core KMDJ23, $7.56 \mathrm{~m}$ long, is located on the crest of the lower ridge in the distal part of the sediment-wave field (location in Figure 1). It is composed of thin sand and silt intervals alternating with accumulations of silty mud, corresponding to a succession of fine-grained turbidite deposits. In the upper 4 meters, the basal layers are about $1 \mathrm{~cm}$ thick and are composed mainly of silt and very fine sand. At $4.2 \mathrm{mbsf}$, there is a coarser layer with structureless massive medium sand. Between 4.5 and 6.4 mbsf, the turbidite deposits are silty but more closely spaced (about 8 turbidite deposits in 1 meter). Finally, in the deepest part of the core (below $6.4 \mathrm{mbsf}$ ), the turbidite deposits are thicker and coarser, with a 20-cm-thick interval of medium sand. Core KMDJ23 is more silty and shows a thicker sandy base than core KMDJ22. The transition between two distinct sedimentary facies (finegrained turbidites to sand layers at about $6.4 \mathrm{mbsf}$ ) is well marked and can be correlated with a continuous seismic reflector on CHIRP profile Kmdjsar32 (blue reflector in Figure 7).

Piston core PSM-KS19, $8.20 \mathrm{~m}$ long, is located on the distal part of the lower ridge, downslope of the sediment-wave field. Core PSM-KS19 is composed of a succession of silt and sand layers alternating with accumulations of silty mud; this lithology corresponds to a succession of fine-grained turbidites. The vertical succession of turbidite deposits is relatively irregular with alternating very fine-grained sequences and sandy and thicker sequences. At the base of the core $(8.20 \mathrm{mbsf})$, there is a layer of 


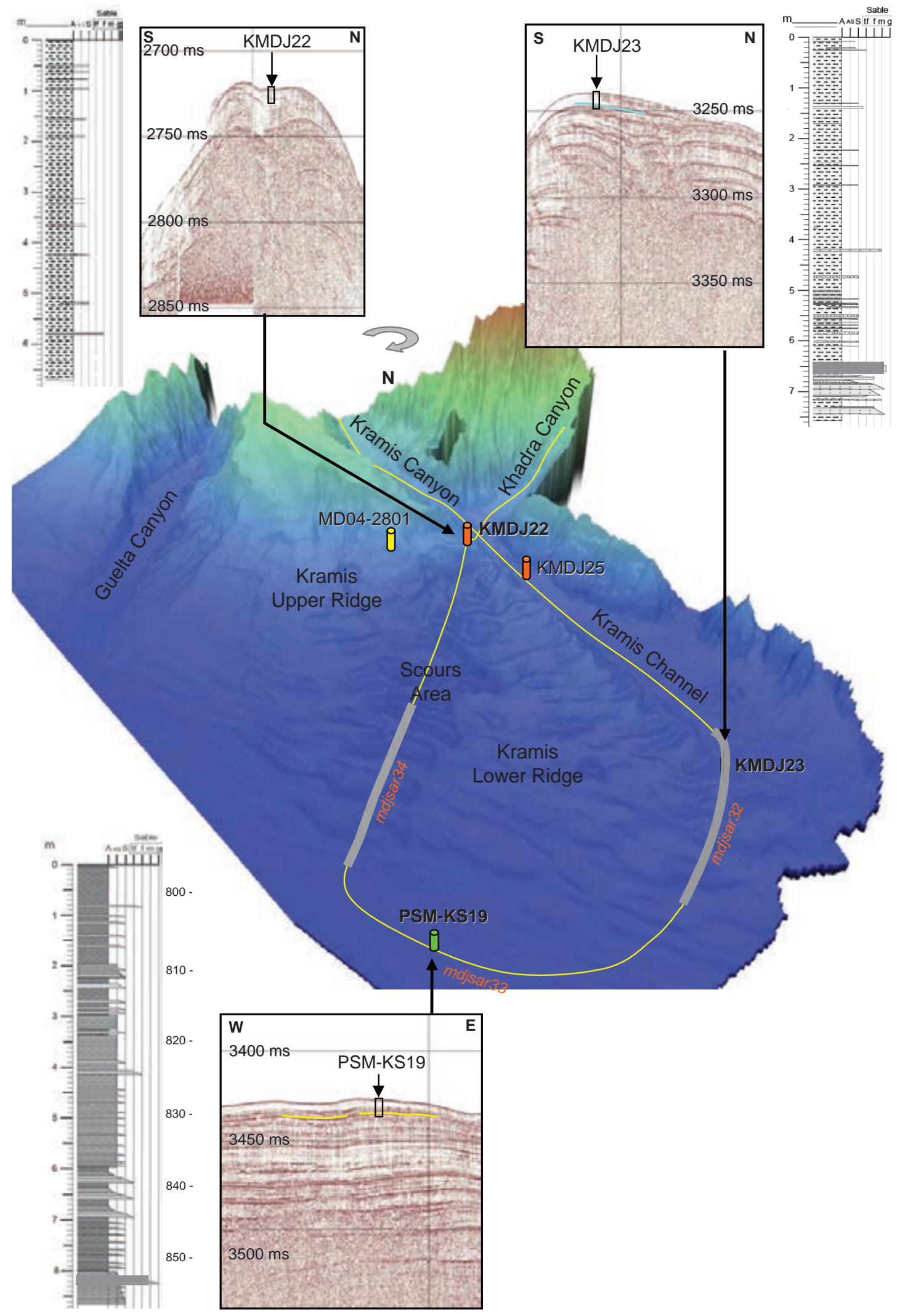

FIG. 7.-3D view of the Kramis canyon and fan, from northwest to southeast, where the cores and the SAR navigation are located. This figure also shows the sedimentological logs of the three cores collected on the sediment ridge and their calibration onto Chirp echo-sounder sections. 
coarse sand with a high content of pteropods. This layer can be correlated with a continuous seismic reflector on CHIRP profile Mdjsar33 (yellow reflector in Figure 7). In this distal area of the Kramis Fan and Ridge, the turbidites are relatively coarse and indicate that turbidity currents feeding this area have enough energy to transport fine sand. The sediment is probably provided by the currents largely overflowing the medium part of the ridge (scour area) and participating in the formation of sediment waves and scours.

KMDJ07 piston core, $6.36 \mathrm{~m}$ long, is located in the westernmost end of the Kramis Fan (Fig. 1). It is composed of a succession of silt and sand layers alternating with muddy intervals. Most of these deposits correspond to thin fine-grained turbidites, with centimeters-thick layers composed of silt or very fine sand. Two turbidites are thicker and coarser. They are respectively located at $4.30 \mathrm{mbsf}$ and $6 \mathrm{mbsf}$ and are characterized by an interval of massive medium sand 15-20 cm thick. Core KMDJ07 is similar to core KMDJ23 in terms of sedimentary facies and vertical organization. Giresse et al. (2009) dated with radiocarbon the sediment at $1.02-1.03,3.91-3.97$, and $5.86-5.89$ mbsf with minimum ages of $4.410 \mathrm{ka}, 15.098 \mathrm{ka}$, and $14.094 \mathrm{ka}$ cal BP, respectively; reworking of older turbidite deposits might explain the age inversion.

\section{Sedimentary Processes Inferred from Morphology and Sediment Cores}

The eastern area of the Kramis Ridge corresponds to the right-hand levee bordering the lower part of the Kramis Canyon, upstream of the Kramis and Khadra Canyon convergence (Fig. 8). The eastern ridge has a crest between 120 and $200 \mathrm{~m}$ high above the canyon floor and is characterized by sediment waves with a morphology relatively attenuated by a thick hemipelagic drape (10 m of hemipelagic mud in MD04-1801). Much of this eastern ridge has likely not been fed by turbidity-current overspill from the canyon in recent times (as proved by the recent hemipelagic sedimentation in MD04-1801). However, the lower part of the eastern ridge crest, which is less than $120-150 \mathrm{~m}$ above the canyon floor, is probably fed by recent turbidity-current flow stripping, as shown by the fine-grained turbidite sequences in the upper sections of core KMDJ22 (located in the ridge crest just upslope of the scours area). The detailed morphology of the eastern ridge also reveals recent gravity processes, especially in the uppermost part, where two scarps are visible near the ridge crest (Fig. 8). Downdip, these two small scarps developed into channelized features that merge together westward and reach the scours area. The two small scarps were not caused by turbidity-current overspill from the canyon, because there are no traces of erosion upslope. They probably were generated by successive slope instabilities (possibly triggered by earthquakes) at the ridge crest, in the area where the gradient is the highest (Fig. 8). This is reminiscent of other example of instabilities in the outer crests of sedimentary ridges, for the example the Var Ridge (Migeon et al., 2011).

The scours area separates the eastern from the western ridge and is located downstream of the convergence point of the Khadra and Kramis canyons (Fig. 8). It is a succession of accretionary bedforms and scoured troughs covering an area 3-7 km wide across the ridge. The process responsible for the formation of scours results from the overspill and the acceleration of the flow exiting the Kramis Channel. In the scours area, the Kramis Ridge crest has an elevation lower than $50 \mathrm{~m}$ above the channel floor. This location corresponds to a point of massive overflow of turbidity currents over the Kramis Ridge, corresponding to the crossing of the Khadra Canyon with the
Kramis Canyon. The intersection of the two canyons might cause flows from the Khadra Canyon to experience a hydraulic jump and an increase in flow thickness that would enhance the overspill process.

The western ridge area is downstream of the convergence of Kramis and Khadra Canyons and is also a point of massive overspill (Fig. 8). The levee relief is relatively irregular, from 110 $\mathrm{m}$ high to less than $30 \mathrm{~m}$ high above the channel floor. The orientation of sediment-wave crests is perpendicular to the channel trend along the crest and becomes oblique in the lower part of the ridge. This suggests that the waves were formed by flows that overstepped the channel but that were still flowing almost parallel to the channel (Fig. 8). Sediment waves are particularly well expressed all along the levee crest, indicating a continuous overspill of turbidity currents. The currents can easily overflow and provide coarse sediments to the levee crest. The high variability of the thickness and grain size of the turbidite deposits collected in core KMDJ23 is probably related to the flow energy and size of the currents flowing in the Kramis Channel.

\section{DISCUSSION}

\section{Evolution and Asymmetry of the Kramis Fan}

The Kramis Fan has an atypical morphology compared to some of the classic examples of deep-sea fans described in the literature (Bouma et al., 1985; Pickering et al., 1995) and fan depositional models composed of canyons, channel-levee systems, and distal lobes complexes (Mutti, 1992; Normark, 1978; Reading and Richards, 1994; Walker, 1978). The Kramis Fan morphology is markedly asymmetrical and quite similar to that of the Var Fan (Mulder et al., 1998; Piper and Savoye, 1993), as illustrated in Figure 9.

The Kramis Fan seems to have been initiated after the Messinian salinity crisis, during the Pliocene. It probably developed first as a relatively symmetrical channel-levee system perpendicular to the base of the slope (Fig. 4), then it migrated westward by avulsion, and finally it migrated farther westward by progressive lateral migration and aggradation of the right-hand levee to its present location parallel to the base of the slope. The present asymmetry is probably the result of a long-term process. In this respect, the evolution through time of the Kramis Fan could be similar to that of the Var Fan. Through time, the Var Channel, which is now directed parallel to the coastline towards the east, has progressively migrated to its present location (Savoye et al., 1993). The configuration of the Var Channel and the curvature of the Var Valley path towards the east at the foot of the slope may have favored the overflow processes and the aggradation of the Var Ridge (Migeon et al., 2000).

The asymmetry and super-developed levee (the Kramis Ridge) on the side opposite to the continental slope could be linked to channel confinement at the base of the slope and to the role of the Coriolis effect (Pérenne et al., 2001; Wells, 2009). Another mechanism could involve the interaction of the canyon flows with bottom currents (Kuvaas et al., 2005; Massé et al., 1998). Oceanographic data of the Western Mediterranean (Millot, 1999) show that the "Algerian Current" is dominated by flows from west to east along the Algerian margin with local unstable mesoscale eddies. In these conditions, the circulation of water masses could favor the overflow of turbidity currents in the eastern side of turbidite channels and the growth of a superdeveloped eastern levee (the Kramis Ridge). However, the eastward migration of the Kramis Channel cannot be directly explained by this process. 


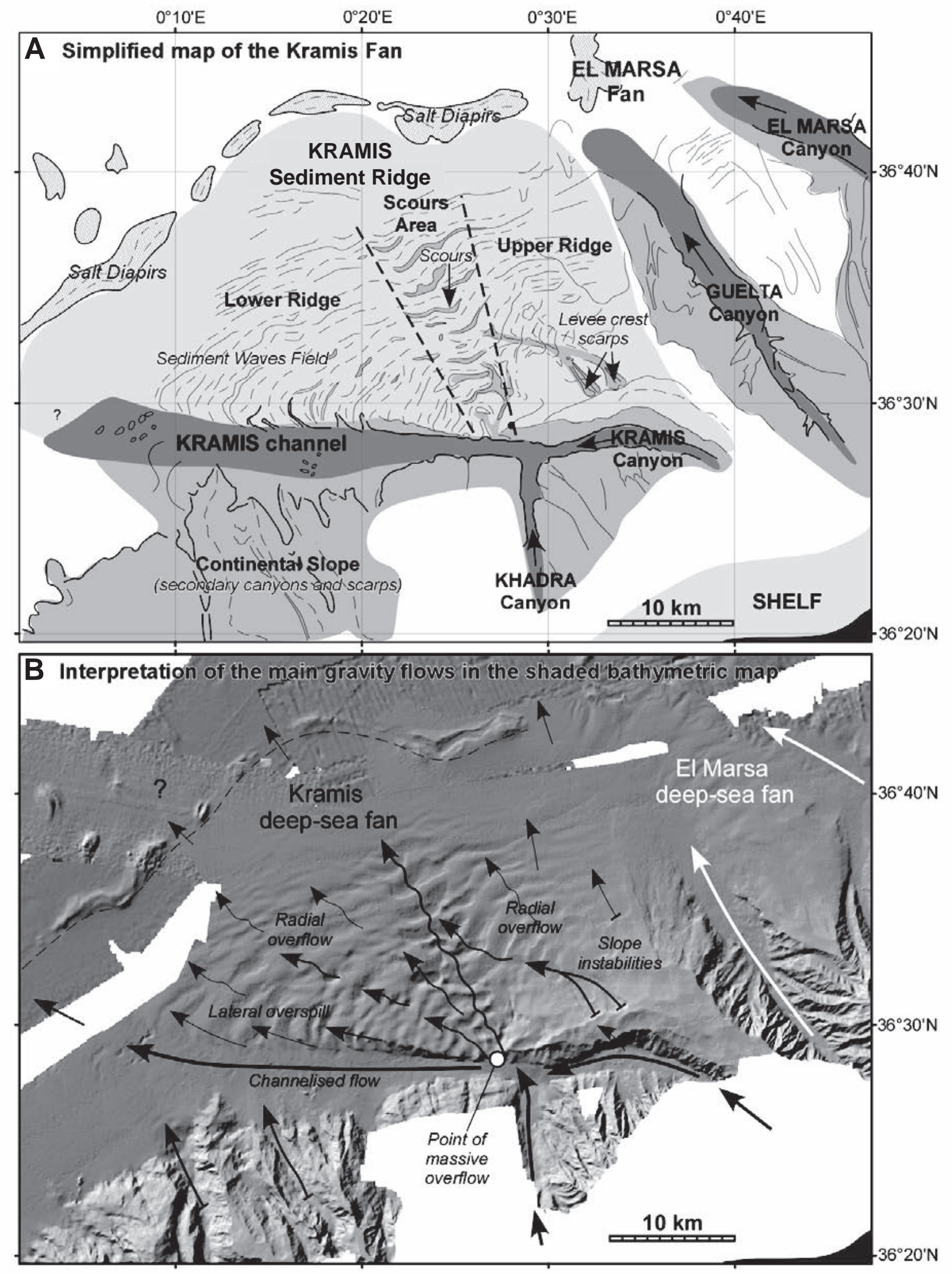

FIG. 8. - Interpretation in terms of turbidity flows and direction over the Kramis fan, including A) the simplified morphological map of the fan and $\mathbf{B}$ ) the interpretation of the main gravity-flow direction based on a shaded bathymetric map. 


\section{Var system}

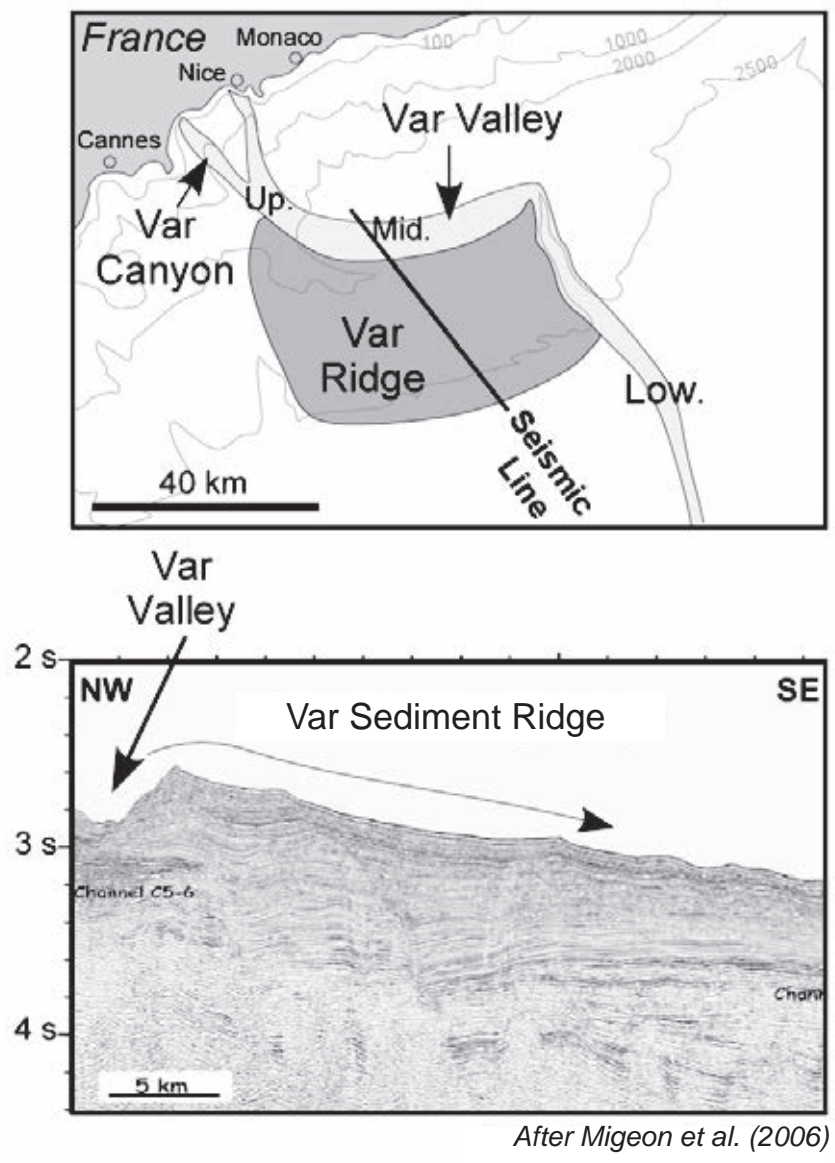

Kramis system

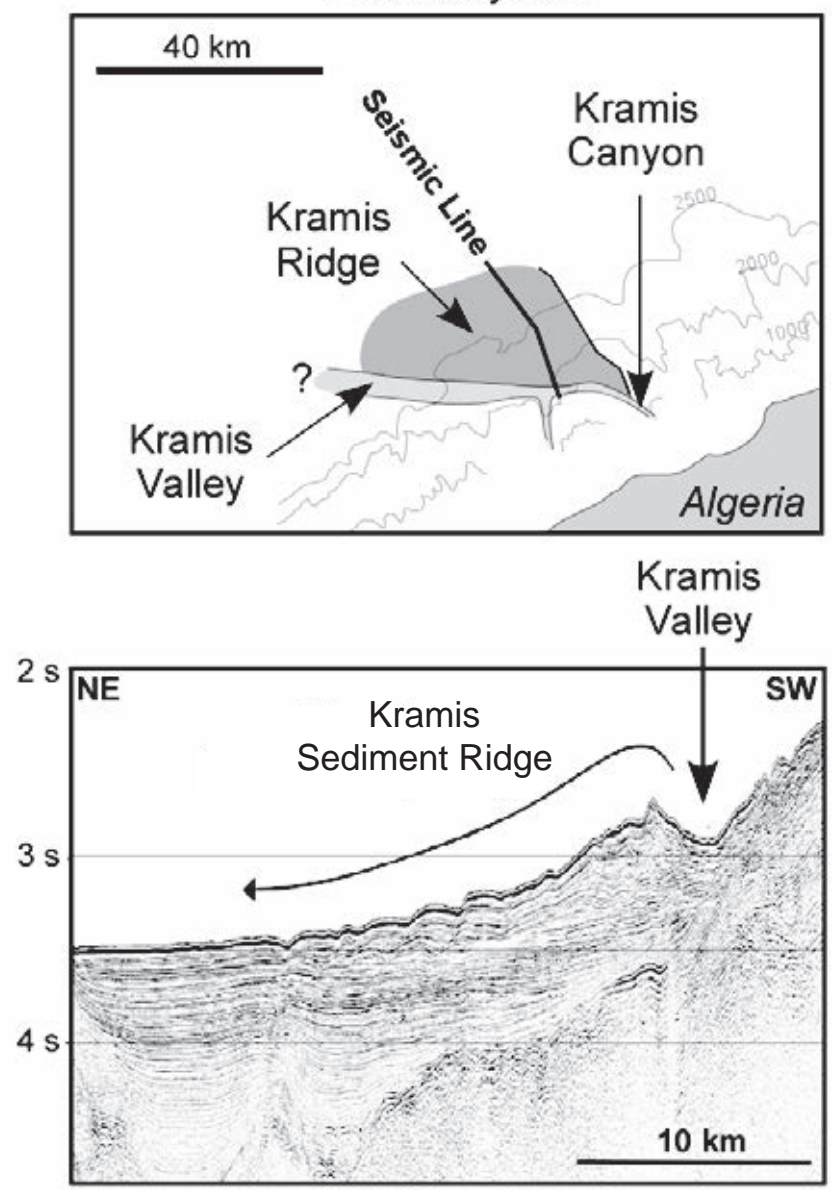

FIG. 9.-Comparison between the Var (Migeon et al., 2006) and Kramis turbidite systems at the same scale. In both systems there is a large sediment ridge on the right side of the channel, which runs roughly parallel to the margin. The Var Ridge appears larger in extent, but the available data does not allow representation of the distal part of the Kramis Ridge. In seismic lines, the Kramis Ridge shows a shallower valley (or channel) and higher-amplitude sediment waves than the Var Ridge, possibly because of the lesser degree of confinement of turbidity flows in the Kramis Channel (or Valley) and the overspill of Khadra Canyon turbidites over the Kramis Ridge.

The migration and the confinement of the Kramis Channel along the base of the slope could also be linked to a structural control, because this margin is actively deforming under a compressional regime (Déverchère et al., 2005; Domzig et al., 2006; Yelles et al., 2009). However, the overall geometry and the internal architecture of the ridge suggest that the main aggradation of the ridge is related to overflow from the Kramis Canyon and Channel system.

\section{Enhancement of Sediment Waves and Scours by Canyon Crossing and Flow Interaction}

The sediment waves of the Kramis Fan compare relatively well with case studies presented in the literature, but, especially in the scours area (Fig. 2), they present some peculiarities that deserve discussion to reconstruct the processes responsible for their enhanced morphology (Figs. 5, 8). Sediment waves deposited from fine-grained turbidity currents display characteristic bedform dimensions including wave heights up to $80 \mathrm{~m}$ and wavelengths up to $7 \mathrm{~km}$, with most waves being developed on slopes of $0.1-0.7^{\circ}$ (Wynn and Stow, 2002). Sediment-wave dimensions generally decrease downslope, in response to the gradient, the distance from the source, and sediment supply. Sediment-wave asymmetry also decreases downslope, with more asymmetrical waves developed in areas with higher sediment supply and steeper slope (Migeon et al., 2004; Migeon et al., 2000; Normark et al., 2002). Like sediment waves described in the literature for turbidite levees (Wynn and Stow, 2002), sediment waves of the Kramis eastern and western ridges are asymmetrical, and their amplitude and asymmetry decrease downslope, whereas wavelengths increases downslope. The crest directions are perpendicular to the regional slope, showing the radial dispersion of currents over the eastern ridge.

Several studies have concluded that multiple models of sediment-wave formation should be considered depending on grain size of the deposits and interpreted characteristics of the flows (Migeon et al., 2004). The antidune model is more appropriate where the sediments are sandy and the flows are 
supercritical. For silty-muddy deposits like the Kramis ridge, the sediment waves develop as the result of separation across the bedforms by subcritical flows carrying suspended load. Decreased gradient and decreased bed shear stress on the stoss sides of the bedforms results in enhanced deposition, and increased gradient and increased bed shear stress on the lee sides of the bedforms results in reduced deposition, nondeposition, or erosion (Migeon et al., 2004; Migeon et al., 2000; Nakajima and Satoh, 2001; Normark et al., 2002). Increased sedimentation rate on the upstream sides of the bedforms leads to upslope sediment-wave migration, in the direction opposite to the turbidity-current flows.

Along the Kramis channel ridge crest, the sediment waves are aligned along the ridge crest. These morphologies can be explained by a particular overflow dynamic in the proximal part of the levee, which can be interpreted as continuous overspill of the currents (Hiscott et al., 1997). The wave-crest directions and shape indicate that the overspill currents are probably parallel to the channel, implying that flow thickness is much higher than the levee. However, the high amplitude of the sediment waves in the distal part of the ridge crest (Fig. 2, profile D) is probably amplified by turbidity currents coming from secondary canyons incising the continental slope to the south (Fig. 8).

The morphology of the scours area corresponds to a linear series of steps with scour-shaped depressions, aligned downstream of the point of massive overflow (Fig. 8). Similar structures have previously been described along the Monterey East Channel by Fildani at al. (2006): they consist of giant scours aligned downstream from a breach in the levee on the southern side of the Shepard Meander and are interpreted as "cyclic steps" resulting from significant flow stripping. Numerical modelling suggests that the steps in the Monterey system were created by unstable Froude-supercritical turbidity currents, in which the flows passed through alternating phases of erosion and deposition after successive hydraulic jumps (Fildani et al., 2006). The processes generating the successive scours of the Kramis Ridge are probably similar and are interpreted to be related to high-energy currents generated by flow stripping. As in the Monterey system (Fildani et al., 2006), there is lateral continuity between scours and sediment waves located on both sides. This type of structure with cyclic steps could be the initial stage in the development of a new channel across the ridge. In the Kramis Ridge, processes responsible for the scour incision could be the same, but the flow-stripping process is not generated in the external part of a meander: it probably results from turbidity currents with a flow direction perpendicular to the Kramis Ridge flank. The scours could postdate the Kramis Ridge growth and result in the erosional modification of the ridge, induced by recent turbidity-current activity coming from the Khadra Canyon.

The interaction or superposition of bottom currents of distinct origin have been demonstrated to be a potential factor enhancing seafloor shaping with the formation of both sediment waves and scours (Trincardi et al., 2007; Verdicchio and Trincardi, 2006). In the case of the Kramis Fan, the interaction of distinct flows could include the turbidity flows from the Kramis Canyon causing the ridge growth by levee overspill and the turbidity flows coming from the Khadra Canyon, intersecting the Kramis Channel perpendicularly. It is not clear whether the two fluxes acted simultaneously or the turbidity currents from the Khadra Canyon acted in a second time to rework the ridge.

Another possible evidence of flow interaction is represented by the morphology of the high-amplitude sediment waves in the Kramis channel ridge crest of the western Ridge (Figure 2, section
D). Also in the El Marsa turbidity system such a mechanism could be inferred from the morphology of the fan downslope the intersection of the Guelta and El Marsa Canyons. All of this evidence points to canyon convergence as a potential factor causing morphological amplifications of sediment waves and erosional scours.

\section{CONCLUSIONS}

The Kramis Fan is a deep-sea fan located in the western part of the Algerian margin. It is fed by two perpendicular canyons: the Kramis Canyon and the Khadra Canyon, merging into a single westward channel confined at the foot of the slope. Its general morphology is asymmetric, with a super-developed ridge on the right-hand side of the channel, similar to the Var Fan off the French Riviera. The Kramis Fan is the result of turbidity-current activity initiated after the Messinian Salinity Crisis. The fan was progressively built at the base of the slope by channel-levee migration and aggradation of the ridge.

The most spectacular feature of the Kramis Ridge is the presence of well-expressed sediment waves at the surface of the ridge. The morphologies of the sediment waves characterize the dynamics of the currents flowing across the Kramis Ridge. The Kramis Ridge is a giant levee built by the overflow of turbidity currents on the right side of the Kramis Canyon and Channel. Sedimentary features like sediment waves and scours show the interaction of different processes at the surface of the ridge: flow stripping, spillover, and superposition of different flow directions. In the central part of the ridge, the sediment waves present erosion on the downslope side with a series of scours, interpreted as cyclic steps. The scours are developed by flow-stripping processes probably linked to turbidity currents flowing perpendicular to the ridge flank, coming from the Khadra Canyon.

The recent development of the ridge is controlled by the activity of turbidity currents both from the Kramis and the Khadra Canyons, with interaction between the two perpendicular directions of sediment source. The scours could postdate the Kramis Ridge growth and result in the erosional modification of the ridge, induced by recent turbidity currents coming from the Khadra Canyon. The succession of scours is linear and could correspond to a new channel initiation, cutting the ridge.

The superposition or the interaction of flows with different directions is probably responsible for the development of the high-amplitude sediment waves and scours observed in the Kramis Fan. In the Algerian margin, several well-developed sediment-wave fields seem to be located in areas subjected to interaction of different flow directions. This could be an important factor explaining the amplification of the size of sediment waves and scours in this margin and also in other margins.

\section{ACKNOWLEDGMENTS}

The authors would like to thank the captain, crew members, and technical staff on board R/V Le Suroît during the Maradja 1 and 2 cruises (2003 and 2005), on board R/V Marion Dufresne during Prisma cruise (2004), and on board R/V L'Atalante during Prisme cruise (2007). Special thanks to N. Sultan (Ifremer), chief scientist of Prisma and Prisme cruises. This work was financially supported by ANR (Agence Nationale de la Recherche) projects ISIS and DANACOR.

This paper is homage to Bruno Savoye, who initiated the study of Algerian deep-sea fans in collaboration with Jacques Déverchère. The study of the Kramis fan had a particular interest for him, for its similarities with the Var fan and the spectacular sediment-wave forms. Bruno's death is an enormous loss for marine geosciences 
and mostly for his family, friends, colleagues, and students. Our sympathy goes to Babette, his wife, and to Charlotte and Marion, his daughters.

\section{REFERENCES}

BfG (The German Federal Institute of Hydrology), 1999, Global Runoff Data Centre. <http: / / grdc.bafg.de/servlet/is/Entry.987.Display / >

Boudiaf, A., 1996, Etude sismotectonique de la région d'Alger et de la Kabylie (Algérie): utilisation des modèles numériques de terrain (MNT) et de la télédétection pour la reconnaissance des structures tectoniques actives: Contribution à l'évaluation de l'aléa sismique: Université Montpellier 2, Montpellier, 274 p.

Boudjadja, A., Messahal, M., and Pauc, H., 2003, Ressources hydriques en Algérie du Nord. Assessment of Water Resources in Northern Algeria: Revue des Sciences de l'Eau, v. 16, p. 285-304.

BOUMA, A.H., NoRMARK, W.R., AND BARNES, N.E., 1985, Submarine Fans and Related Turbidite Systems: New York, Springer-Verlag, 351 p.

Cattaneo, A., Babonneau, N., Dan, G., Déverchère, J., Domzig, A., Gaullier, V., Lepillier, B., Lépinay, B.M., Nouguès, A., Strzerzynski, P., Sultan, N., AND YelLes, K., 2010, Submarine landslides along the Algerian Margin: A review of their occurrence and potential link with tectonic structures, in Mosher, D.C., Shipp, C., Moscardelli, L., Chaytor, J., Baxter, C., Lee, H., and Urgeles, R., eds., Submarine Mass Movements and Their Consequences, Advances in Natural and Technological Hazards Research: Berlin, Springer, v. 28, p. 507-518.

Dan, G., Sultan, N., Savoye, B., Déverchère, J., and Yelles, K., 2008, Quantifying the role of sandy-silty sediments in generating slope failures during earthquakes: example from the Algerian margin: International Journal of Earth Sciences, v. 98, p. 769-789, doi:10.1007 / s00531-008-0373-5.

Déverchère, J., Yelles, K., Domzig, A., Mercier de Lépinay, B., Bouillin, J.-P., Gaullier, V., Bracène, R., Calais, E., Savoye, B., Kherroubi, A., LeRoy, P., PAUC, H., AND DAN, G., 2005, Active thrust faulting offshore Boumerdes, Algeria, and its relations to the $2003 \mathrm{Mw} 6.9$ earthquake: Geophysical Research Letters, v. 32, L04311, doi:10.1029/2004 GL021646.

Domzig, A., Gaullier, V., Giresse, P., Pauc, H., Déverchère, J., And Yelles, K., 2009, Deposition processes from echo-character mapping along the western Algerian margin (Oran-Tenes), Western Mediterranean: Marine and Petroleum Geology, v. 26, p. 673-694, doi:10.1016/ j.marpetgeo.2008.05.006.

Domzig, A., Yelles, K., Le Roy, C., Déverchère, J., Bouillin, J.-P., Bracène, R., Mercier de Lépinay, B., Le Roy, P., Calais, E., Kherroubi, A., Gaullier, V., SAvoye, B., AND Pauc, H., 2006, Searching for the AfricaEurasia Miocene boundary offshore western Algeria (MARADJA'03 cruise): Comptes Rendus Geosciences, v. 338, p. 80-91, doi:10.1016/ j.crte.2005.11.009.

Dos ReIs, A.T., Gorini, C., AND Mauffret, A., 2005, Implications of saltsediment interactions on the architecture of the Gulf of Lions deepwater sedimentary systems-western Mediterranean Sea: Marine and Petroleum Geology, v. 22, p. 713-746, doi:10.1016/j.marpetgeo. 2005.03.006.

El-Robrini, M., Gennesseaux, M., AND Mauffret, A., 1985, Consequences of the El-Asnam Earthquake: Turbidity currents and slumps on the Algerian margin (Western Mediterranean): Geo-Marine Letters, v. 5, p. 171-176.

Fildani, A., Normark, W.R., Kostic, S., AND Parker, G., 2006, Channel formation by flow stripping: large-scale scour features along the Monterey East Channel and their relation to sediment waves: Sedimentology, v. 53, p. 1265-1287.

HeEZEN, B.C., AND EwING, M., 1954, Orléanville earthquake and turbidity currents: American Association of Petroleum Geologists, Bulletin, v. 39, p. 2505-2514.

HiscotT, R.N., HALL, F.R., AND Pirmez, C., 1997, Turbidity-current overspill from the Amazon Channel: texture of the silt/sand load, paleoflow from anisotropy of magnetic susceptibility and implications for flow processes, in Flood, R.D., Piper, D.J.W., Klaus, A., and Peterson, L.C., eds., Proceedings of the Ocean Drilling Program, Scientific Results, v. 155 , p. 53-78.

KuvaAs, B., KRistoffersen, Y., Guseva, J., LeitchenKov, G., GANDJuKhin, V., LøvÅs, O., SAND, M., AND BREKKE, H., 2005, Interplay of turbidite and contourite deposition along the Cosmonaut Sea / Enderby Land margin, East Antarctica: Marine Geology, v. 217, p. 143-159, doi:10.1016/ j.margeo.2005.02.025.

LeCLAIRE, L., 1972, La sédimentation holocène sur le versant méridional Algérro-Baléares (Précontinent Algérien): Museum National Histoires Naturelles, Paris, 392 p.

Lofi, J., Gorini, C., Berné, S., Clauzon, G., Tadeu Dos Reis, A., Ryan, W.B.F., AND STECKLER, M.S., 2005, Erosional processes and paleo-environmental changes in the Western Gulf of Lions (SW France) during the Messinian Salinity Crisis: Marine Geology, v. 217, p.1-30, doi:10.1016/ j.margeo.2005.02.014.

MASSÉ, L., FAUGÈRES, J.C., AND Hrovatin, V., 1998, The interplay between turbidity and contour current processes on the Columbia Channel fan drift, Southern Brazil Basin: Sedimentary Geology, v. 115, p. 111-132.

MAUfFret, A., 2007, The Northwestern (Maghreb) boundary of the Nubia (Africa) Plate. Tectonophysics, v. 429, p. 21-44, doi:10.1016/ j.tecto.2006.09.007.

Mauffret, A., Rehault, J.P., Gennesseaux, M., Bellaiche, G., Labarbarie, M., AND LefeBVRE, D., 1998, Western Mediterranean basin evolution: from distensive to compressive regime, in Wetzel, F.C., ed., Sedimentary Basins of Mediterranean Margins: Bologna, C.N.R. Italian Project of Oceanography, p. 61-81.

Meghraoui, M., Cisternas, A., And Philip, H., 1986, Seismotectonics of the Lower Cheliff Basin: structural background of the EL Asnam (Algeria) Earthquake: Tectonics, v. 5, p. 809-836, doi:10.1029/ TC005i006p00809.

Migeon, S., Cattaneo, A., Hassoun, V., Larroque, C., Corradi, N., Fanucci, F., Dano, A., AND Mercier de Lépinay, B., 2011, Morphology, distribution and origin of recent submarine landslides of the Ligurian Margin (North-western Mediterranean): some insights into geohazard assessment: MarineGeophysical Research, v.32, p. 225-243, doi:10.1007/ s11001-011-9123-3.

Migeon, S., Mulder, T., Savoye, B., And Sage, F., 2006, The Var turbidite system (Ligurian Sea, northwestern Mediterranean)—morphology, sediment supply, construction of turbidite levee and sediment waves: implications for hydrocarbon reservoirs: Geo-Marine Letters, v. 26, p. 361-371, doi: 10.1007/ s00367-006-0047-x.

Migeon, S., Savoye, B., Babonneau, N., and Spy-Anderson, F.L., 2004, Processes of sediment-wave construction along the present Zaire deep-sea meandering channel: Role of meanders and flow stripping: Journal of Sedimentary Research, v. 74, p. 580-598, doi: 10.1306/ 091603740580

Migeon, S., SAVOYe, B., AND FAugères, J.C., 2000, Quaternary development of migrating sediment waves in the Var deep-sea Fan: distribution, growth pattern, and implication for levee evolution: Sedimentary Geology, v. 133, p. 265-293, doi:10.1016/S0037-0738(00)00043-9.

Millot, C., 1999, Circulation in the Western Mediterranean Sea: Journal of Marine Systems, v. 20, p. 423-442, doi:10.1016/S0924-7963(98)00078-5. Mulder, T., SAVoye, B., PiPer, D.J.W., AND SyVITSKI, J.P.M., 1998, The Var submarine system: understanding Holocene sediment delivery processes and their importance to the geological record, in Stocker, M.S., Evans, A., and Cramp, A., eds., Geological Processes on Continental Margins: Sedimentation, Mass-Wasting and Stability: Geological Society of London, Special Publication 129, p. 145-166.

MutTI, E., 1992, TurbiditeSandstones: Agip, Istituto di geologia, Università di Parma, Italy, Special Publication, 275 p.

NAKAJIMA, T., AND SATOH, M., 2001, The formation of large mudwaves by turbidity currents on the levees of the Toyama deep-sea channel, Japan sea: Sedimentology, v. 48, p. 435-463, doi:10.1046/j.13653091.2001.00373.x. 
NORMARK, W.R., 1978, Fan valleys, channels, and depositional lobes on modern submarine fans: characters for recognition of sandy turbidite environments: American Association of Petroleum Geologists, Bulletin, v. 62, p. 912-931.

Normark, W.R., Hess, G.R., Stow, D.A.V., AND Bowen, A.J., 1980, Sediment waves on the Monterey Fan levee: A preliminary physical interpretation: Marine Geology, v. 37, p. 1-18, doi:10.1016/0025-3227(80)90009-2.

Normark, W.R., Piper, D.J.W., Posamentier, H., Pirmez, C., And Migeon, S., 2002, Variability in form and growth of sediment waves on turbidite channel levees: Marine Geology, v. 192, p. 23-58, doi:10.1016/S00253227(02)00548-0.

Pérenne, N., Lavelle, J.W., Smith, D.C. and Boyer, D.L., 2001, Impulsively started flow in a submarine canyon: Comparison of results from laboratory and numerical models: Journal of Atmospheric and Oceanic Technology, v. 18, p. 1698-1718, doi: 10.1175/1520-0426(2001)018.

Pickering, K.T., Hiscott, R.N., KenYon, N.H., Ricci Lucchi, F., And Smith, C.E., 1995, Atlas of Deep Water Environments: Architectural Style in Turbidite Systems: London, Chapman \& Hall, 344 p.

PIPER, D.J.W., AND SAVoYE, B., 1993, Processes of late Quaternary turbidity current flow and deposition on the Var deep-sea fan, north-west Mediterranean Sea: Sedimentology, v. 40, p. 557-582, doi:10.1111/ j.1365-3091.1993.tb01350.x.

Probst, J.L., And Amiotte Suchet, P., 1992, Fluvial suspended sediment transport and mechanical erosion in Maghreb (North Africa): Hydrological Sciences-Journal des Sciences Hydrologiques, v. 37, p. 621-637.

REAdING, H.G., AND RichaRDS, M., 1994, Turbidite systems in deep-water basin margins classified by grain size and feeder system: American Association of Petroleum Geologists, Bulletin, v. 78, p. 792-822.

SAVOYE, B., PIPER, D.J.W., AND Droz, L., 1993, Plio-Pleistocene evolution of the Var deep-sea fan off the French Riviera: Marine and Petroleum Geology, v. 10, p. 550-571, doi:10.1016/0264-8172(93)90059-2.

Strzerzynski, P., Déverchère, J., Cattaneo, A., Domzig, A., Yelles, K., Mercier de Lépinay, B., BabONnEAU, N., AND Boudiaf, A., 2010, Tectonic inheritance and Pliocene-Pleistocene inversion of the Algerian margin around Algiers: Insights from multibeam and seismic reflection data: Tectonics, v. 29, TC2008, doi:10.1029/2009TC002547.

TrinCARDI, F., VerdicChIO, G., AND MiseroCCHI, S., 2007, Seafloor evidence for theinteraction between cascading and along-slopebottom water masses: Journal of Geophysical Research, v. 112, F03011, doi:10.1029/ 2006JF000620.

VerdicCHIO, G., AND TRINCARDI, F., 2006, Short-distance variability in slope bed-forms along the Southwestern Adriatic Margin (Central Mediterranean): Marine Geology, v. 234, p. 271-292, doi:10.1016/ j.margeo.2006.09.007.

WALKER, R.G., 1978, Deep-water sandstone facies and ancient submarine fans: models for exploration for stratigraphic traps: American Association of Petroleum Geologists, Bulletin, v. 62, p. 932-966.

Wells, M.G., 2009, How Coriolis forces can limit the spatial extent of sediment deposition of a large-scale turbidity current: Sedimentary Geology, v. 218, p. 1-5, doi:10.1016/j.sedgeo.2009.04.011.

Wrnn, R.B., Masson, D.G., Stow, D.A.V., And Weaver, P.P.E., 2000, Turbidity current sediment waves on the submarine slopes of the western Canary Islands: Marine Geology, v. 163, p.185-198, doi:10.1016/S00253227(99)00101-2.

WYNN, R.B., AND STOW, D.A.V., 2002, Classification and characterisation of deep-water sediment waves: Marine Geology, v. 192, p. 7-22, doi:10.1016/S0025-3227(02)00547-9.

Yelles-Chaouche, A., Boudiaf, A., Djellit, H., and Bracene, R., 2006, La tectonique active de la région nord-algérienne: Comptes Rendus Geosciences, v. 338, p. 126-139, doi:10.1016/j.crte.2005.11.002.

Yelles, A., Domzig, A., Déverchère, J., Bracène, R., Mercier de Lépinay, B., Strzerzynski, P., Bertrand, G., Boudiaf, A., Winter, T., Kherroubi, A., Le Roy, P., And DJellit, H., 2009, Plio-Quaternary reactivation of the Neogene margin off NW Algiers, Algeria: The Khayr al Din bank: Tectonophysics, p. 475, p. 98-116, doi:10.1016/j.tecto.2008.11.030. 